Supplementary Information

for

\title{
Cocrystallization of Trimethoprim and Solubility Enhancement via Salt Formation
}

\author{
Qixuan Zheng, Daniel K. Unruh, and Kristin M. Hutchins* \\ Department of Chemistry and Biochemistry, Texas Tech University, 1204 Boston Avenue, Lubbock, \\ Texas 79409, United States. \\ *Email: kristin.hutchins@ttu.edu
}

1. Experimental details

2. X-ray diffraction information and data tables

3. Single-crystal X-ray structures

4. NMR data for crystals

5. TGA data

6. DSC data

7. Solubility, melting point, and stability experiments

8. Dissolution rate experiments

9. PXRD patterns

10. References
Page S1

Page S2-S4

Page S5-S6

Page S7-S10

Page S11-S12

Page S13-S14

Page S15

Page S16

Page S17-S21

Page S22 


\title{
1. Experimental details
}

\begin{abstract}
Materials
Trimethoprim (TMP), isonicotinic acid (INA), 4,4-dipyridyl (4,4'-BIPY), and nitromethane were purchased from Oakwood Chemical (Columbia Hwy N. Estill, SC, USA). 1,2-Bis(4-pyridyl)ethylene (4,4'BPE) and 4,4'-azopyridine (4,4'-AP) were purchased from Sigma-Aldrich Chemical (St. Louis, MO, USA). Nicotinic acid (NA) was purchased from Tokyo Chemical Industry Co., LTD (Toshima, Kita, Tokyo, Japan). Lastly, methanol, ethanol, chloroform, toluene, and acetone were purchased from Fisher Scientific (Lenexa, KS, USA).
\end{abstract}

\section{Cocrystallizations}

Cocrystals of TMP.4,4'-BPE were synthesized by dissolving TMP (20 mg, $0.07 \mathrm{mmol}$ ) and 4,4'-BPE (12.6 mg, $0.07 \mathrm{mmol}$ ) in acetone or chloroform. Slow evaporation of the solution was allowed for a period of 4-5 days until single crystals were formed that were suitable for X-ray diffraction.

Cocrystals of TMP.4,4'-AP were synthesized by dissolving TMP (20 mg, $0.07 \mathrm{mmol})$ and 4,4'-AP (12.9 $\mathrm{mg}, 0.07 \mathrm{mmol}$ ) in methanol. The solution was allowed to evaporate slowly over a period of 4-5 days until single crystals were formed that were suitable for X-ray diffraction.

Cocrystals of TMP.4,4'-BIPY were synthesized by dissolving TMP (20 mg, $0.07 \mathrm{mmol})$ and 4,4'-BIPY (10.9 $\mathrm{mg}, 0.07 \mathrm{mmol}$ ) in ethanol. The solution was allowed to evaporate slowly over a period of 4-5 days until single crystals were formed that were suitable for X-ray diffraction.

Salt-hydrates of TMP·NA $\cdot \mathbf{H}_{2} \mathbf{O}$ were synthesized by dissolving TMP (20 mg, $\left.0.07 \mathrm{mmol}\right)$ and NA (17.2 $\mathrm{mg}, 0.14 \mathrm{mmol}$ ) in ethanol or toluene/acetone. The solution was allowed to evaporate slowly over a period of 4-5 days until single crystals were formed that were suitable for X-ray diffraction.

Salts of TMP·NA EtOH were synthesized by dissolving TMP (20 mg, $0.07 \mathrm{mmol})$ and NA (17.2 mg, 0.14 $\mathrm{mmol}$ ) in ethanol in a sealed container filled with drierite. The solution was allowed to evaporate slowly over a period of about 1 month until single crystals were formed that were suitable for X-ray diffraction.

Salts of TMP·INA $\cdot \mathbf{M e N O}_{2}$ were synthesized by dissolving TMP $(20 \mathrm{mg}, 0.07 \mathrm{mmol})$ and INA $(17.2 \mathrm{mg}$, $0.14 \mathrm{mmol}$ ) in nitromethane. If wet solvent is used for cocrystallization, water can be incorporated into the lattice. This can be eliminated by using dry solvent or crystallization in water/air free environment. The solution was allowed to evaporate slowly over a period of 15-20 days until single crystals were formed that were suitable for X-ray diffraction.

\section{Mechanochemistry experiments}

Mechanochemical synthesis experiments were conducted for TMP·NA $\cdot \mathbf{H}_{2} \mathbf{O}$, TMP.NA EtOH, and TMP.INA $\cdot \mathrm{MeNO}_{2}$ to determine if the cocrystals could be synthesized by milling. A FTS1000 Ball Mill purchased from Form-Tech Scientific was used. Experiments were conducted in $15 \mathrm{~mL}$ stainless steel jars with $10 \mathrm{~mm}$ stainless steel grinding balls. For the $1: 2$ molar ratio experiments, TMP $(20 \mathrm{mg}, 0.07 \mathrm{mmol})$, NA $(17.2 \mathrm{mg}, 0.14 \mathrm{mmol})$, or INA $(17.2 \mathrm{mg}, 0.14 \mathrm{mmol})$ and 1 drop of water, ethanol, or nitromethane were placed in a stainless steel SmartSnap jar. For the 1:1 molar ratio experiments, TMP (40 mg, 0.14 mmol), NA $(17.2 \mathrm{mg}, 0.14 \mathrm{mmol})$, or INA $(17.2 \mathrm{mg}, 0.14 \mathrm{mmol})$ and 1 drop of water, ethanol, or nitromethane were placed in a stainless steel SmartSnap jar. The solvent used for milling is identical to the solvent present in the cocrystal structures. The mixture was milled at $900 \mathrm{rpm}$ for a period of $1 \mathrm{hr}$. The resulting solids were characterized by PXRD. 


\section{X-ray diffraction information and data tables}

X-ray data were collected on a Rigaku XtaLAB Synergy-i Kappa diffractometer equipped with a PhotonJeti X-ray source operated at $50 \mathrm{~W}(50 \mathrm{kV}, 1 \mathrm{~mA})$ to generate $\mathrm{Cu} \mathrm{K \alpha}$ radiation $(\lambda=1.54178 \AA)$ and a HyPix$6000 \mathrm{HE}$ HPC detector. Crystals were transferred from the vial and placed on a glass slide in polyisobutylene. A Zeiss Stemi 305 microscope was used to identify a suitable specimen for X-ray diffraction from a representative sample of the material. The crystal and a small amount of the oil were collected on a MiTiGen cryoloop and transferred to the instrument where it was placed under a cold nitrogen stream (Oxford 700 series) maintained at a given temperature (see tables below) throughout the duration of the experiment. The sample was optically centered with the aid of a video camera to insure that no translations were observed as the crystal was rotated through all positions. After data collection, the unit cell was re-determined using a subset of the full data collection. Intensity data were corrected for Lorentz, polarization, and background effects using the CrysAlis ${ }^{\text {Pro }}{ }^{1}$ A numerical absorption correction was applied based on a Gaussian integration over a multifaceted crystal and followed by a semi-empirical correction for adsorption applied using the program SCALE3 ABSPACK. ${ }^{2}$ The SHELX-2014, ${ }^{3}$ series of programs was used for the solution and refinement of the crystal structure. Hydrogen atoms bound to carbon, nitrogen, and oxygen atoms were located in the difference Fourier map and were geometrically constrained using the appropriate AFIX commands.

We also conducted variable-temperature single-crystal X-ray diffraction experiments for TMP•4,4'-BPE and TMP-4,4'-AP at temperatures of $190 \mathrm{~K}, 210 \mathrm{~K}, 230 \mathrm{~K}, 250 \mathrm{~K}, 270 \mathrm{~K}$, and $290 \mathrm{~K}$, respectively. While these are not discussed in detail in the main text, the CCDC numbers are 2025614-2025619 and 20359772035982, respectively. 
Table S1. X-ray data for cocrystals TMP.4,4'-AP, TMP·4,4'-BPE, and TMP-4,4'-BIPY.

\begin{tabular}{|c|c|c|c|}
\hline compound name & TMP.4,4'-AP & TMP.4,4'-BPE & TMP.4,4'-BIPY \\
\hline chemical formula & $\mathrm{C}_{24} \mathrm{H}_{26} \mathrm{~N}_{8} \mathrm{O}_{3}$ & $\mathrm{C}_{26} \mathrm{H}_{28} \mathrm{~N}_{6} \mathrm{O}_{3}$ & $\mathrm{C}_{43} \mathrm{H}_{48} \mathrm{~N}_{11} \mathrm{O}_{6}$ \\
\hline formula mass & 388.24 & 472.54 & 814.92 \\
\hline crystal system & Triclinic & Triclinic & Triclinic \\
\hline space group & $P \overline{1}$ & $P \overline{1}$ & $P \overline{1}$ \\
\hline $\mathrm{a} / \AA$ & 10.4001 & 10.4351 & 9.03900 \\
\hline $\mathrm{b} / \AA$ & 11.7686 & 11.5279 & 10.5908 \\
\hline $\mathrm{c} / \AA$ & 12.0059 & 11.8747 & 11.5825 \\
\hline$\alpha /^{\circ}$ & $99.165^{\circ}$ & $100.2966^{\circ}$ & 111.864 \\
\hline$\beta /{ }^{\circ}$ & $108.983^{\circ}$ & $111.697^{\circ}$ & 97.2850 \\
\hline$\gamma /{ }^{\circ}$ & $112.041^{\circ}$ & $105.046^{\circ}$ & 94.497 \\
\hline $\mathrm{V} / \AA^{3}$ & 1219.83 & 1220.21 & 1011.18 \\
\hline $\mathrm{P}_{\text {cald }} / \mathrm{g} \mathrm{cm}^{-3}$ & 1.292 & 1.286 & 1.338 \\
\hline $\mathrm{T} / \mathrm{K}$ & 200 & 190 & 100 \\
\hline $\mathrm{Z}$ & 2 & 2 & 1 \\
\hline radiation type & $\mathrm{Cu} \mathrm{K} \alpha$ & $\mathrm{Cu} \mathrm{K} \alpha$ & $\mathrm{Cu} \mathrm{K} \alpha$ \\
\hline $\begin{array}{c}\text { absorption coefficient, } \\
\mu / \mathrm{mm}^{-1}\end{array}$ & 0.733 & 0.706 & 0.754 \\
\hline no. of reflections measured & 15680 & 28335 & 35403 \\
\hline $\begin{array}{c}\text { no. of independent } \\
\text { reflections }\end{array}$ & 4993 & 5046 & 4166 \\
\hline no. of reflection $(I>2 \sigma(I))$ & 4266 & 4437 & 3814 \\
\hline $\mathrm{R}_{\text {int }}$ & 0.0311 & 0.0596 & 0.0449 \\
\hline $\mathrm{R}_{1}((\mathrm{I}>2 \sigma(\mathrm{I}))$ & 0.0599 & 0.0434 & 0.0366 \\
\hline$w R\left(F^{2}\right)(I>2 \sigma(I))$ & 0.1665 & 0.1222 & 0.1011 \\
\hline $\mathrm{R}_{1}$ (all data) & 0.0674 & 0.0484 & 0.0393 \\
\hline $\mathrm{wR}\left(\mathrm{F}^{2}\right)$ (all data) & 0.1731 & 0.1268 & 0.1036 \\
\hline Goodness-of-fit & 1.078 & 1.047 & 1.053 \\
\hline CCDC deposition number & 2025620 & 2025614 & 2025621 \\
\hline
\end{tabular}


Table S2. X-ray data for TMP $\cdot \mathbf{N A} \cdot \mathbf{H}_{2} \mathrm{O}$, TMP·NA $\cdot \mathbf{E t O H}$, and TMP $\cdot \mathbf{N A} \cdot \mathbf{M e N O}_{2}$.

\begin{tabular}{|c|c|c|c|}
\hline compound name & $\mathbf{T M P} \cdot \mathbf{N A} \cdot \mathbf{H}_{2} \mathrm{O}$ & TMP.NA $\cdot \mathbf{E t O H}$ & $\mathbf{T M P} \cdot \mathbf{N A} \cdot \mathrm{MeNO}_{2}$ \\
\hline chemical formula & $\mathrm{C}_{20} \mathrm{H}_{25} \mathrm{~N}_{5} \mathrm{O}_{6}$ & $\mathrm{C}_{22} \mathrm{H}_{29} \mathrm{~N}_{5} \mathrm{O}_{6}$ & $\mathrm{C}_{21} \mathrm{H}_{26} \mathrm{~N}_{6} \mathrm{O}_{7}$ \\
\hline formula mass & 431.45 & 459.50 & 474.48 \\
\hline crystal system & Triclinic & Monoclinic & Monoclinic \\
\hline space group & $P \overline{1}$ & $P 2_{1} / c$ & $P 2_{1} / n$ \\
\hline $\mathrm{a} / \AA ̊$ & 4.59790 & 9.50680 & 9.05160 \\
\hline $\mathrm{b} / \AA$ & 12.07920 & 21.3026 & 23.8500 \\
\hline $\mathrm{c} / \AA ̊$ & 18.7055 & 11.6964 & 10.34690 \\
\hline$\alpha /^{\circ}$ & $99.8920^{\circ}$ & $90^{\circ}$ & $90^{\circ}$ \\
\hline$\beta /{ }^{\circ}$ & $94.4370^{\circ}$ & $92.1040^{\circ}$ & $93.9520^{\circ}$ \\
\hline$\gamma /{ }^{\circ}$ & $93.3390^{\circ}$ & $90^{\circ}$ & $90^{\circ}$ \\
\hline $\mathrm{V} / \AA^{3}$ & 1017.66 & 2367.15 & 2228.38 \\
\hline $\mathrm{P}_{\text {calc }} / \mathrm{g} \mathrm{cm}^{-3}$ & 1.408 & 1.289 & 1.414 \\
\hline $\mathrm{T} / \mathrm{K}$ & 100 & 100 & 100 \\
\hline $\mathrm{Z}$ & 2 & 4 & 4 \\
\hline radiation type & $\mathrm{Cu} \mathrm{K} \alpha$ & $\mathrm{Cu} \mathrm{K} \alpha$ & $\mathrm{Cu} \mathrm{K} \alpha$ \\
\hline $\begin{array}{c}\text { absorption coefficient, } \\
\mu / \mathrm{mm}^{-1}\end{array}$ & 0.885 & 0.792 & 0.910 \\
\hline no. of reflections measured & 34355 & 29837 & 38510 \\
\hline $\begin{array}{l}\text { no. of independent } \\
\text { reflections }\end{array}$ & 4191 & 4943 & 4636 \\
\hline no. of reflection $(\mathrm{I}>2 \sigma(\mathrm{I}))$ & 3924 & 4480 & 4324 \\
\hline $\mathrm{R}_{\text {int }}$ & 0.0504 & 0.0396 & 0.0358 \\
\hline $\mathrm{R}_{1}((\mathrm{I}>2 \sigma(\mathrm{I}))$ & 0.0407 & 0.0411 & 0.0366 \\
\hline$w R\left(\mathrm{~F}^{2}\right)(\mathrm{I}>2 \sigma(\mathrm{I}))$ & 0.1161 & 0.1109 & 0.0966 \\
\hline $\mathrm{R}_{1}$ (all data) & 0.0491 & 0.0442 & 0.0393 \\
\hline$w R\left(F^{2}\right)$ (all data) & 0.1167 & 0.1135 & 0.0996 \\
\hline Goodness-of-fit & 1.167 & 1.070 & 1.017 \\
\hline CCDC deposition number & 2025622 & 2025623 & 2025624 \\
\hline
\end{tabular}




\section{Single-crystal X-ray structures}

For the thermal ellipsoid images below, carbon, hydrogen, oxygen, and nitrogen atoms are represented by gray, white, red, and light blue ellipsoids, respectively.

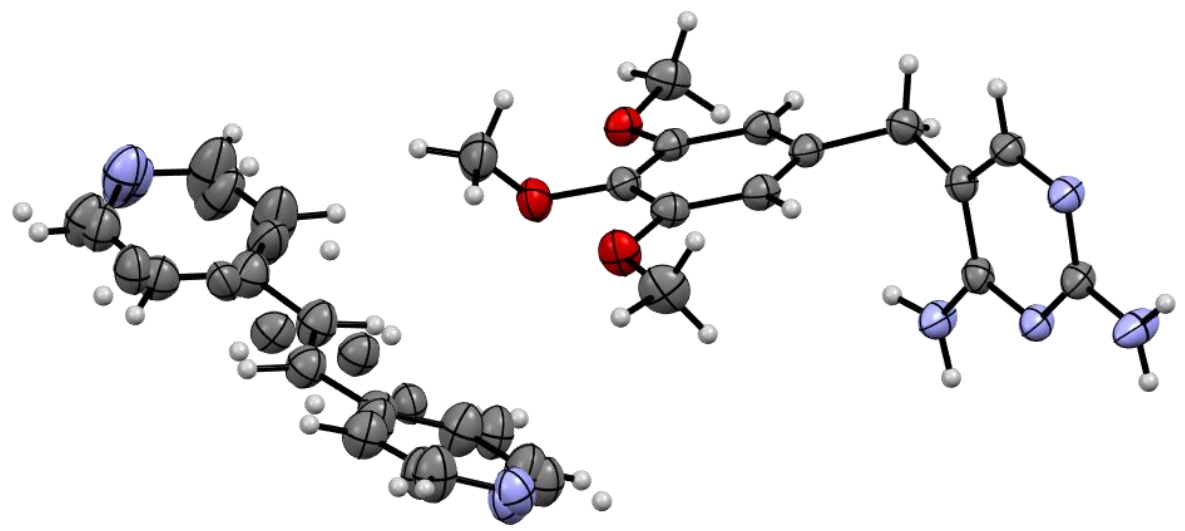

Figure S1. Asymmetric unit of TMP.4,4'-BPE at $190 \mathrm{~K}$ with thermal ellipsoids plotted at $50 \%$ probability.
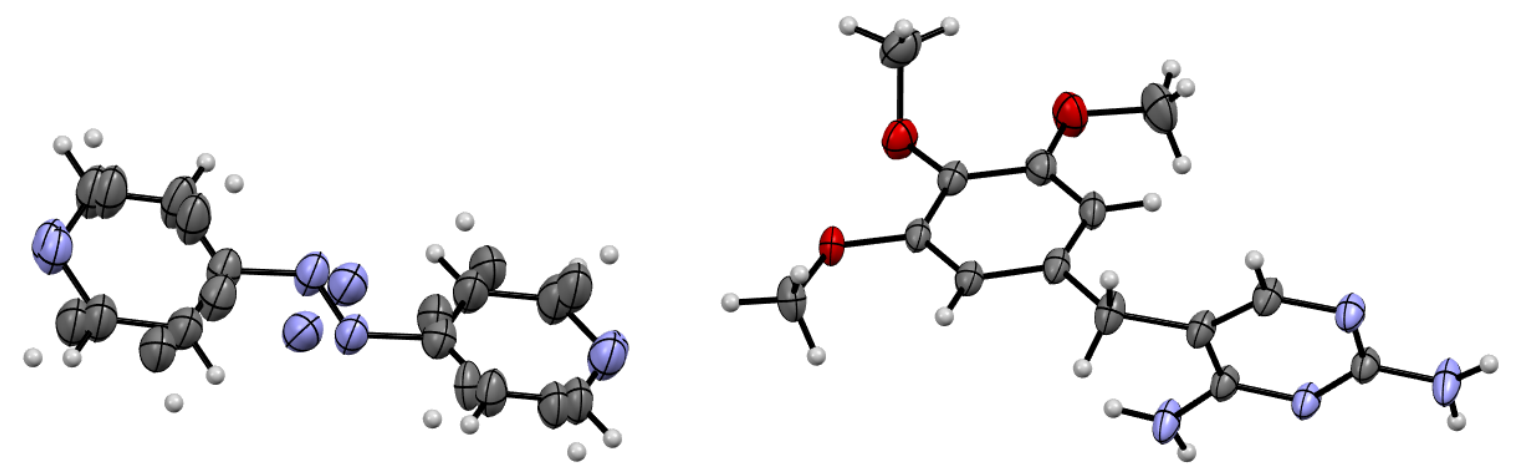

Figure S2. Asymmetric unit of TMP.4,4'-AP at $200 \mathrm{~K}$ with thermal ellipsoids plotted at 50\% probability.

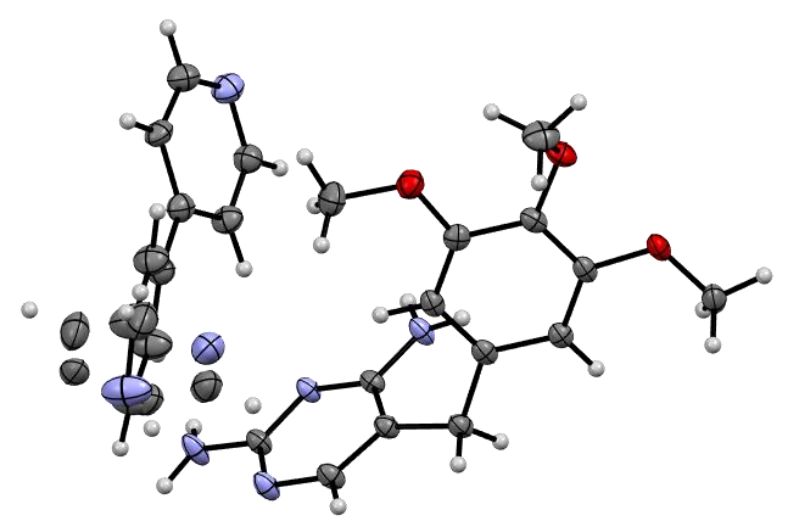

Figure S3. Asymmetric unit of TMP·4,4'-BIPY at $100 \mathrm{~K}$ with thermal ellipsoids plotted at 50\% probability. 


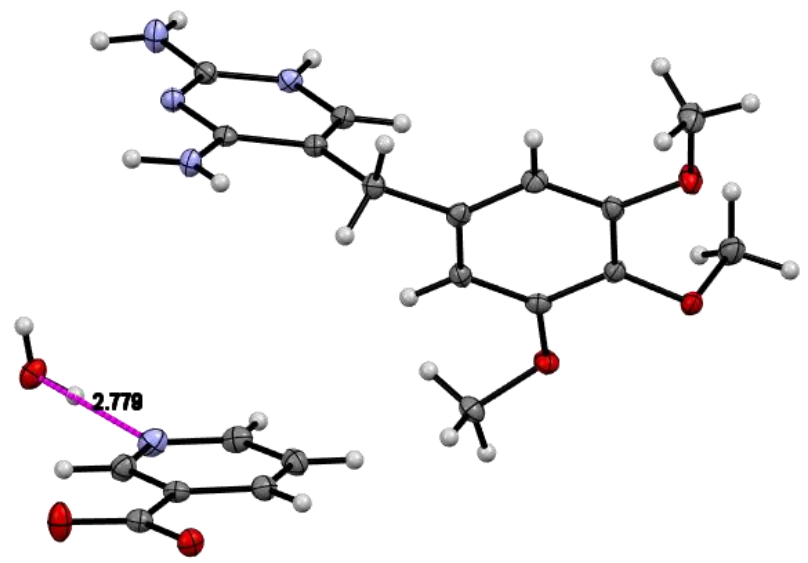

Figure S4. Asymmetric unit of TMP·NA $\cdot \mathbf{H}_{2} \mathbf{O}$ at $100 \mathrm{~K}$ with thermal ellipsoids plotted at $50 \%$ probability.

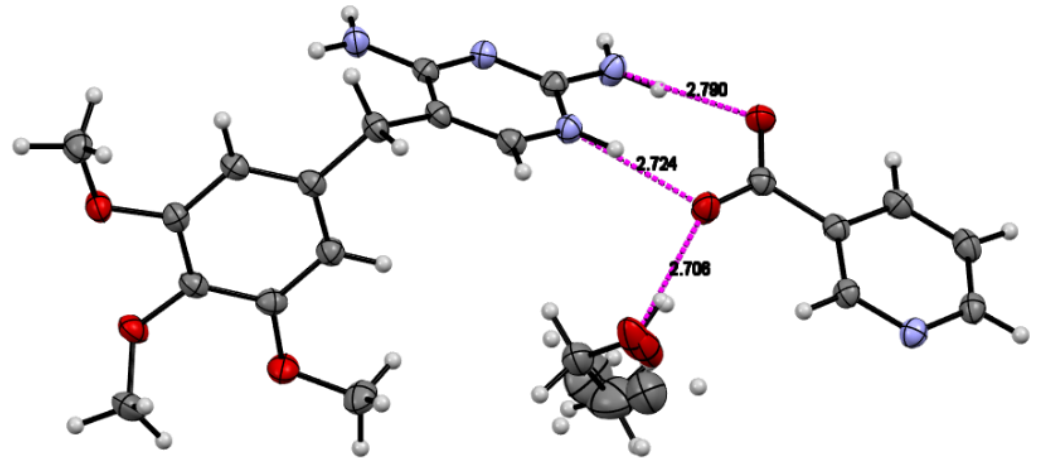

Figure S5. Asymmetric unit of TMP·NA EtOH at $200 \mathrm{~K}$ with thermal ellipsoids plotted at $50 \%$ probability.

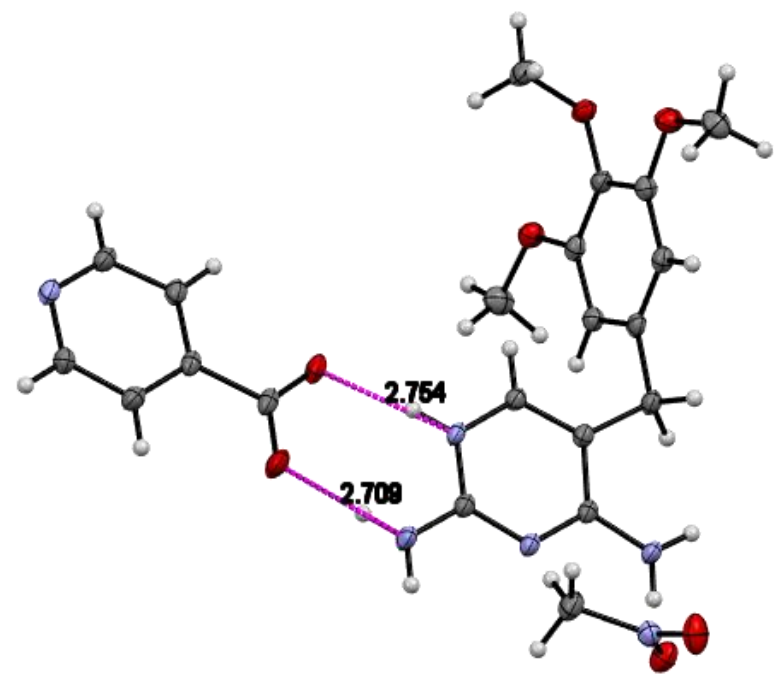

Figure S6. Asymmetric unit of TMP·INA $\cdot \mathbf{M e N O}_{2}$ at $100 \mathrm{~K}$ with thermal ellipsoids plotted at $50 \%$ probability. 


\section{NMR data for crystals}

Single crystals from the cocrystallization experiments were removed from the vial and dissolved in $\mathrm{CDCl}_{3}$ for NMR experiments. NMR data was collected using a JOEL ECS 400 MHZ Spectrometer with multinuclear, direct and inverse detection probes, automatic sample changer, variable temperature, and Zgradient capabilities.
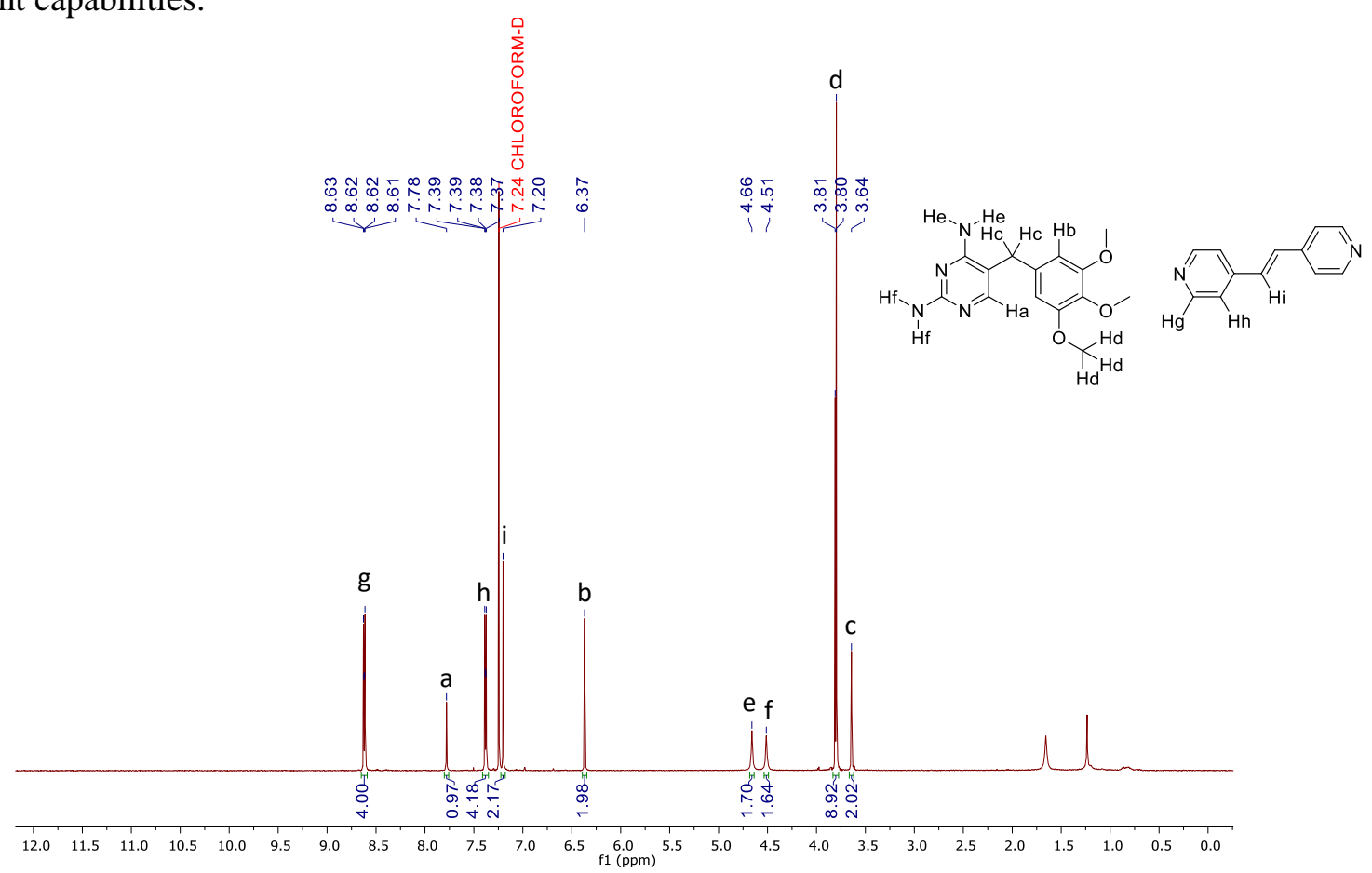

Figure S7. ${ }^{1} \mathrm{H}$ NMR spectrum of cocrystal TMP.4,4'-BPE.

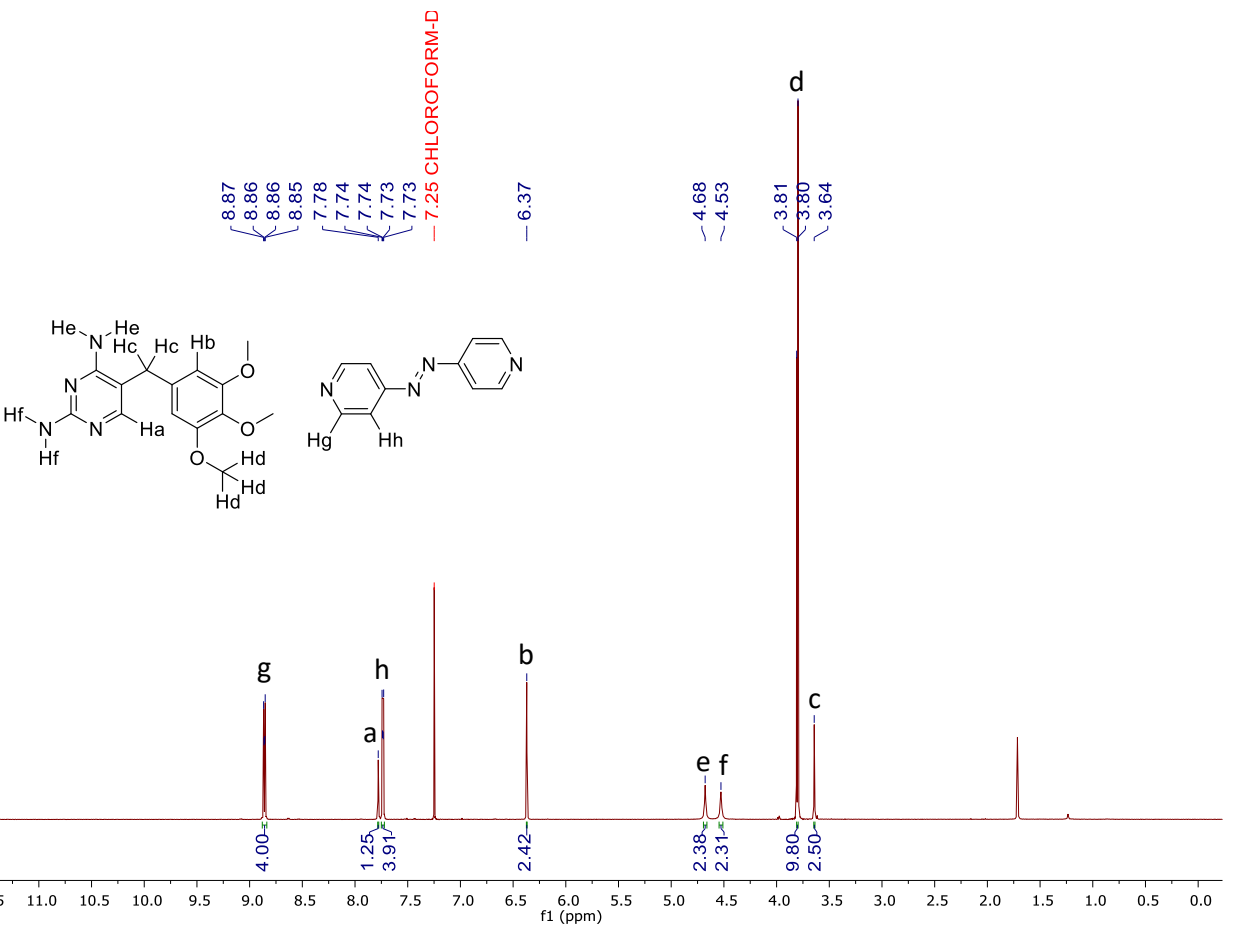

Figure S8. ${ }^{1} \mathrm{H}$ NMR spectrum of cocrystal TMP·4,4'-AP. 


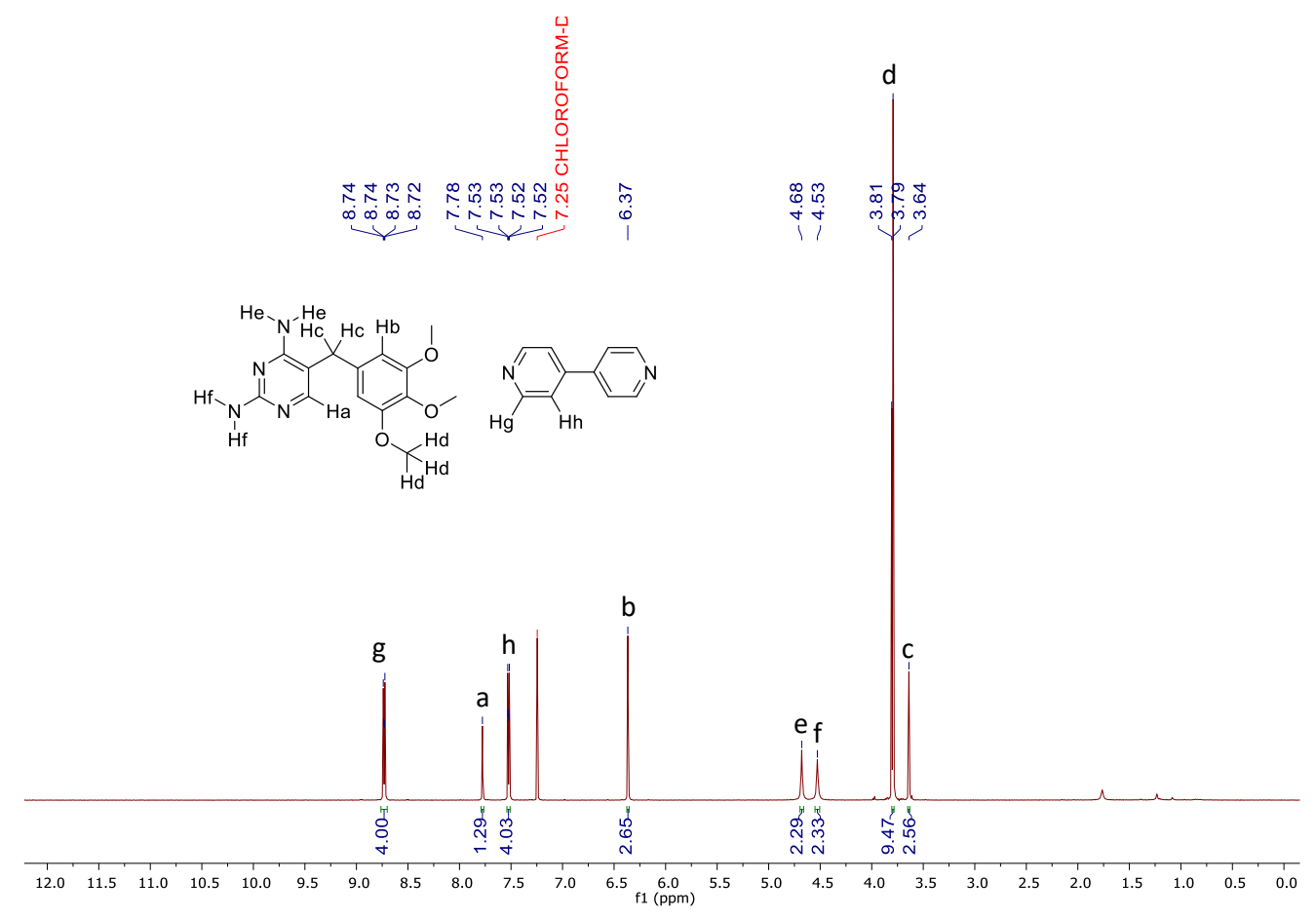

Figure S9. 'H NMR spectrum of cocrystal TMP·4,4'-BIPY.

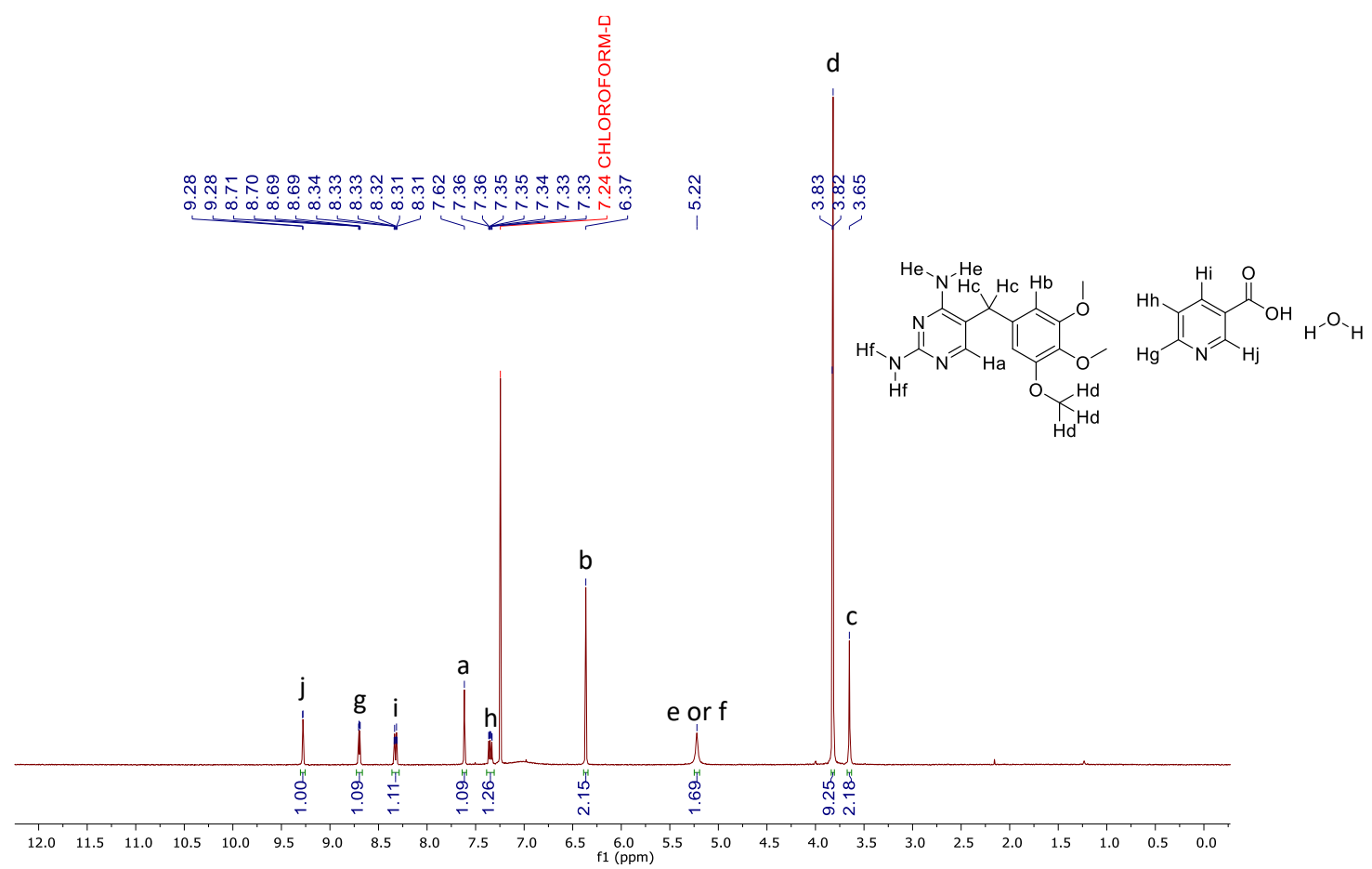

Figure S10. ${ }^{1} \mathrm{H}$ NMR spectrum of salt-hydrate TMP·NA $\cdot \mathbf{H}_{2} \mathbf{O}$. 


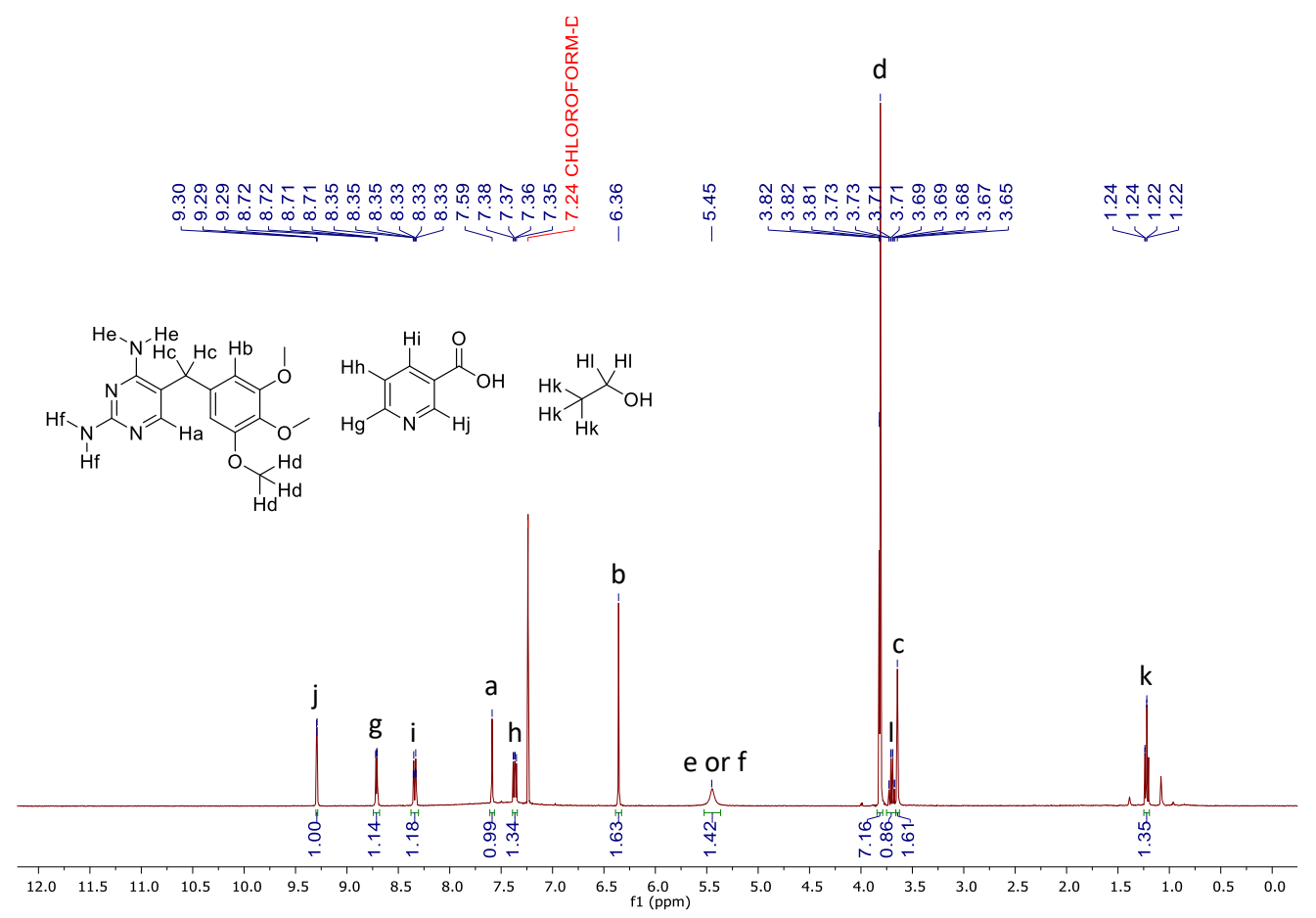

Figure S11. ${ }^{1} \mathrm{H}$ NMR spectrum of salt-solvate TMP·NA EtOH.

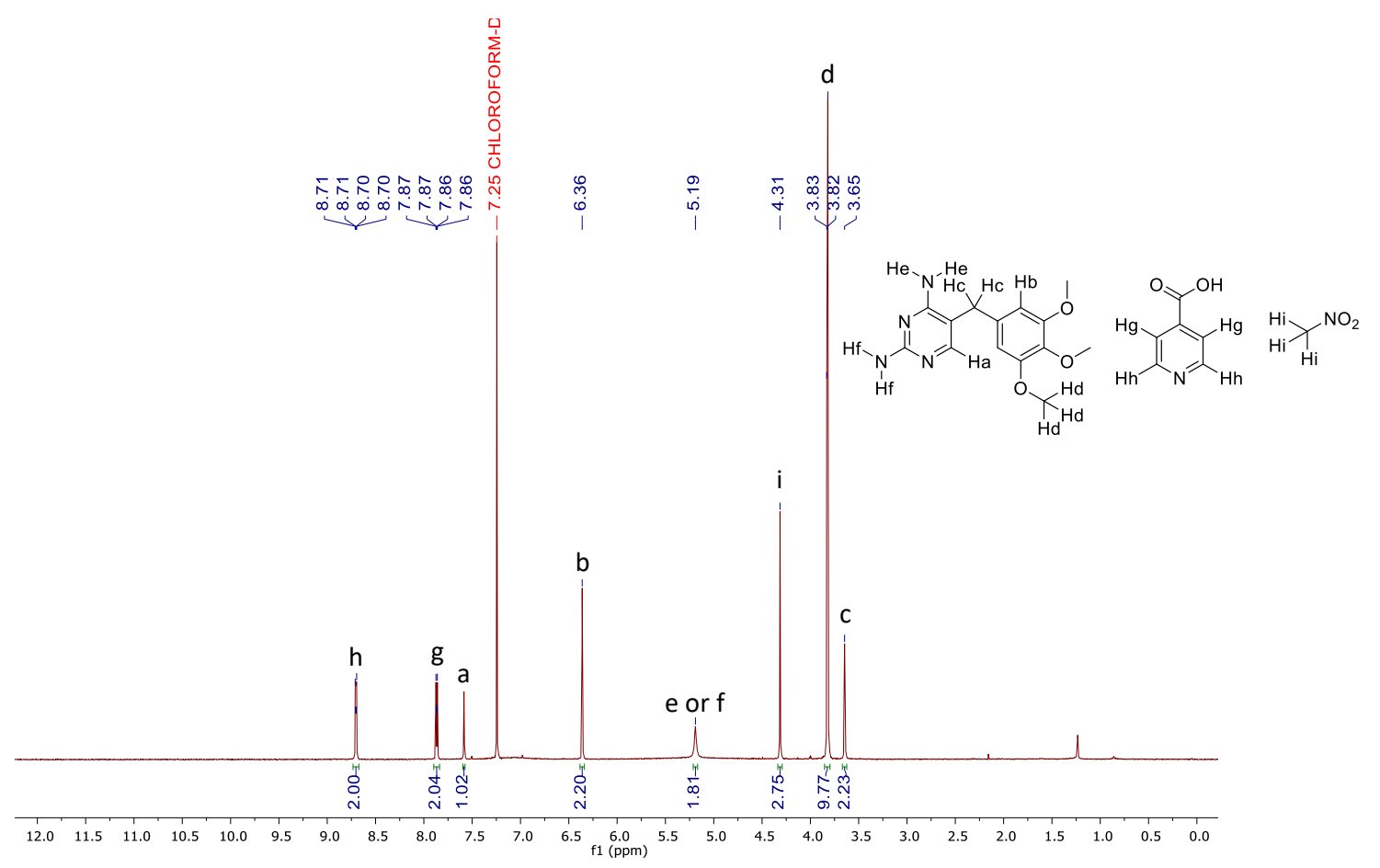

Figure S12. ${ }^{1} \mathrm{H}$ NMR spectrum of salt-solvate TMP·INA $\cdot \mathbf{M e N O}_{2}$. 


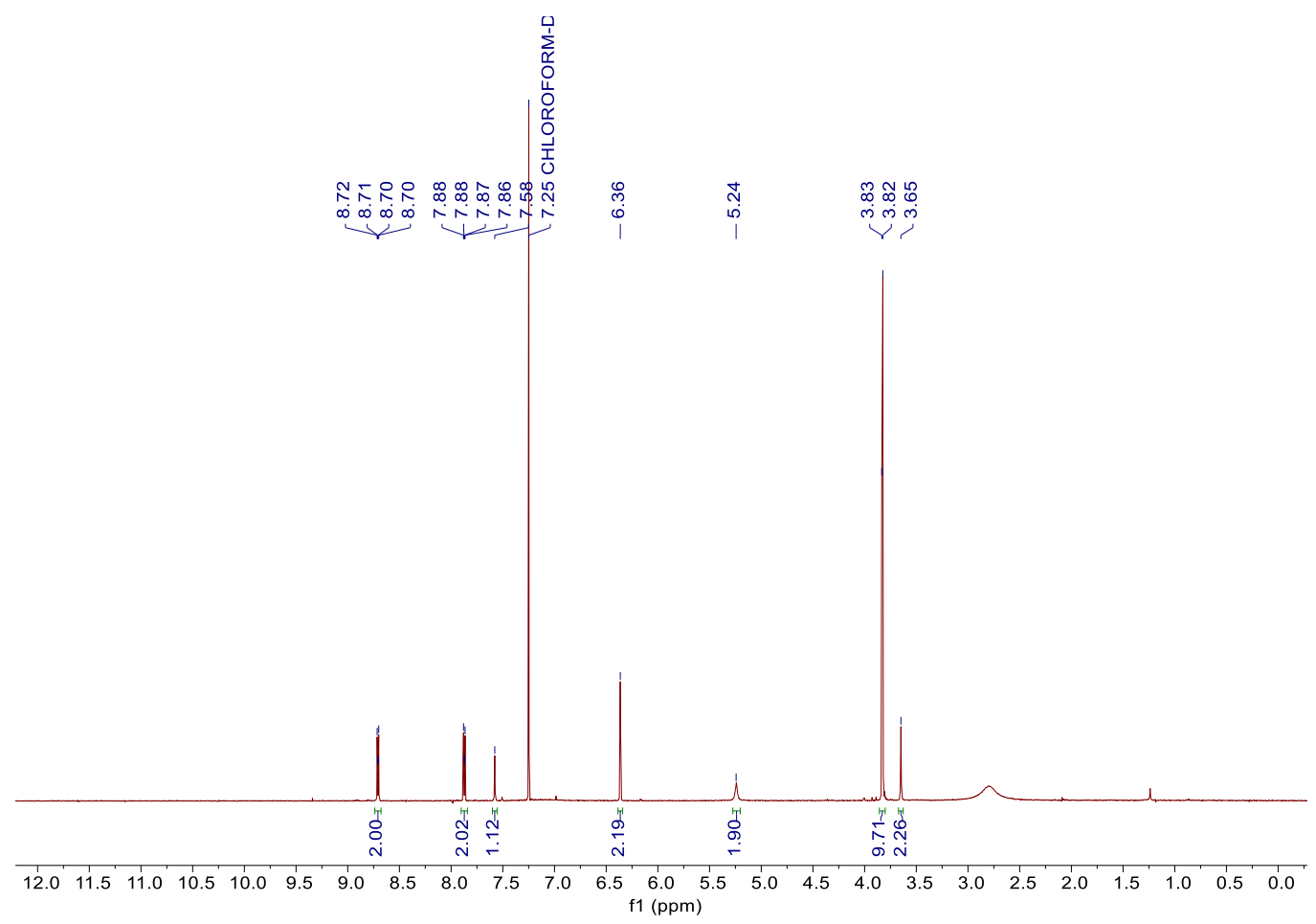

Figure S13. ${ }^{1} \mathrm{H}$ NMR spectrum of TMP.INA $\cdot \mathbf{M e N O}_{2}$ after 10 days of exposure to air and before running PXRD. The nitromethane signal at $4.31 \mathrm{ppm}$ is absent.

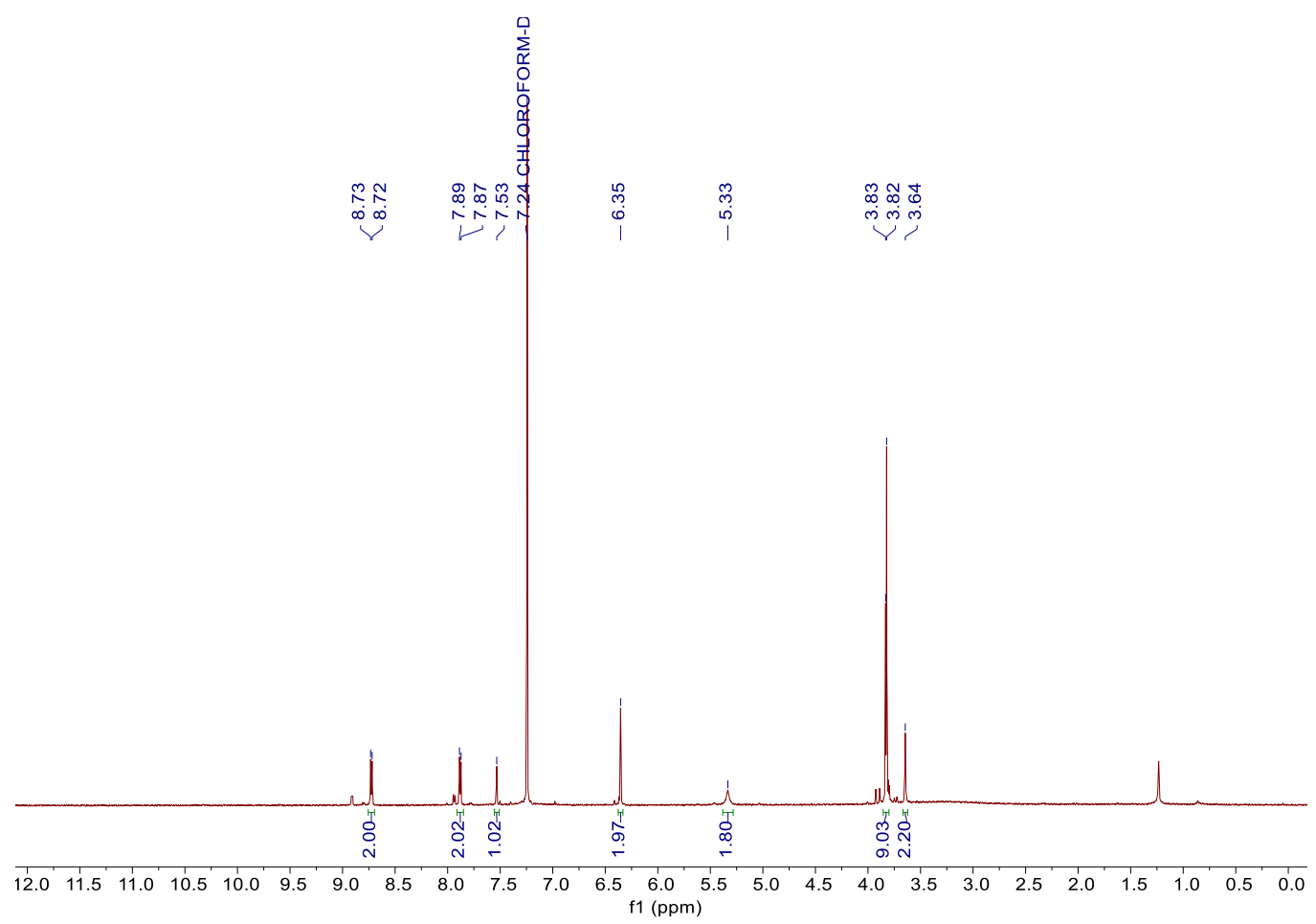

Figure S14. ${ }^{1} \mathrm{H}$ NMR spectrum of salt TMP.INA $\cdot \mathbf{M e N O}_{2}$ after 10 days of exposure to air and after running PXRD. The nitromethane signal at $4.31 \mathrm{ppm}$ is absent. 


\section{TGA data}

A unit cell analysis was performed on the crystals before running the TGA experiments.

TGA data was collected on a Mettler Toledo TGA2. A platinum cell and a nitrogen atmosphere were used. The flow rate was $20 \mathrm{~mL} / \mathrm{min}$, and the heating rate was $10{ }^{\circ} \mathrm{C} / \mathrm{min}$.

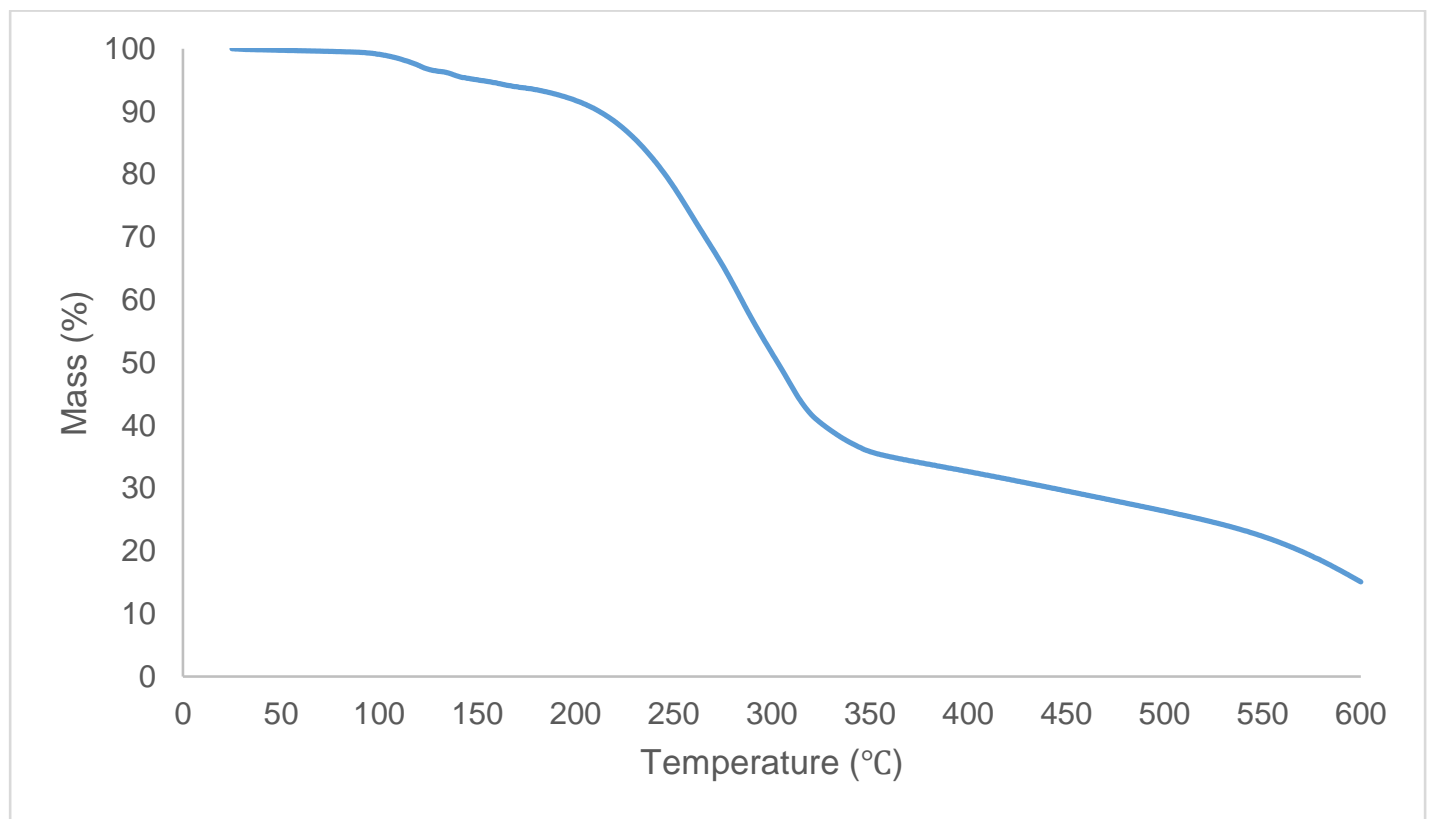

Figure S15. TGA data for solution grown TMP·NA $\cdot \mathbf{H}_{2} \mathbf{O}$. A mass loss of $3.01 \%$ was observed at 96.7 ${ }^{\circ} \mathrm{C}$, and crystal decomposition began at ca. $191.7^{\circ} \mathrm{C}$.

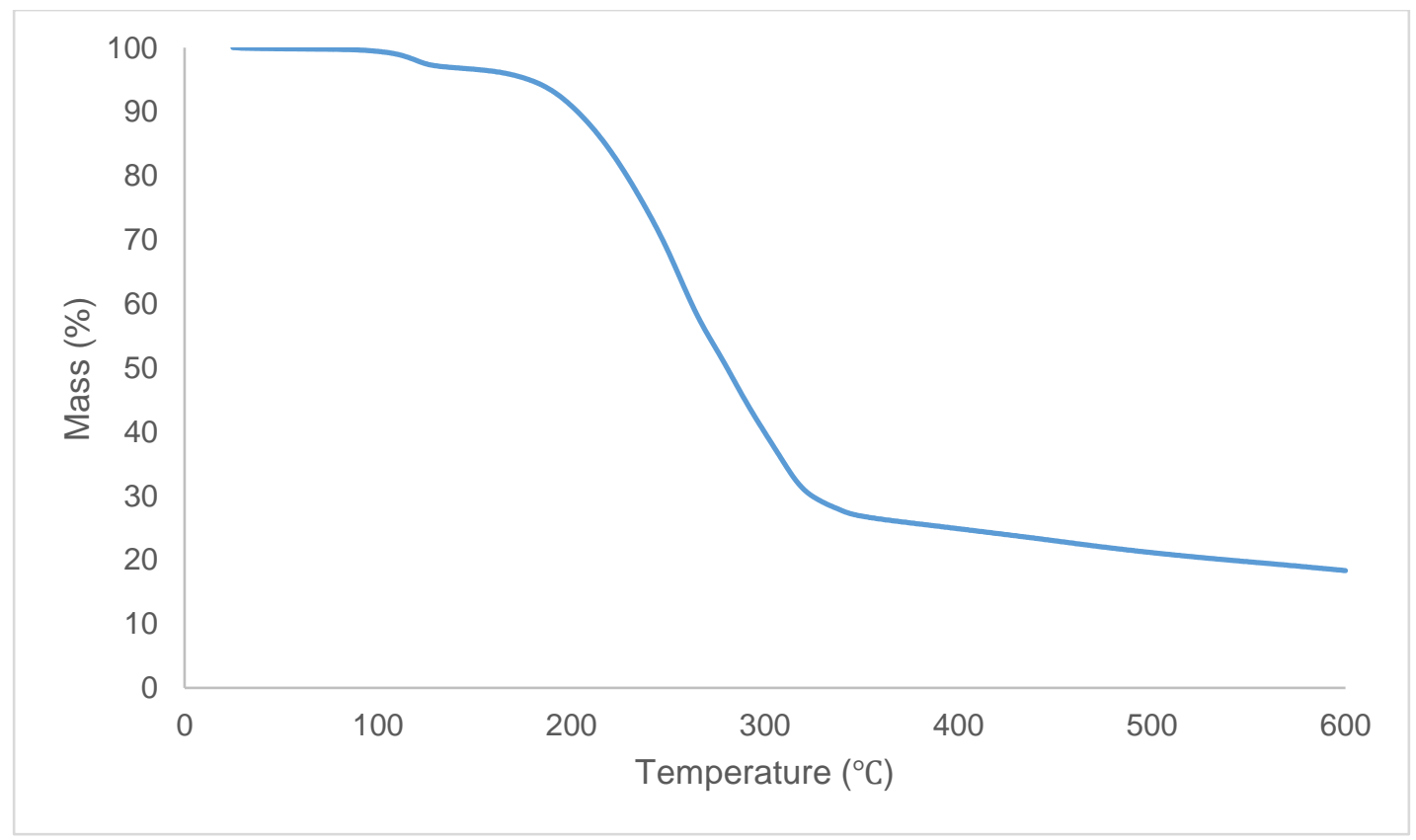

Figure S16. TGA data for solution grown TMP·NA EtOH. A mass loss of $2.84 \%$ was observed at 87.2 ${ }^{\circ} \mathrm{C}$, and crystal decomposition began at ca. $169.6^{\circ} \mathrm{C}$. 


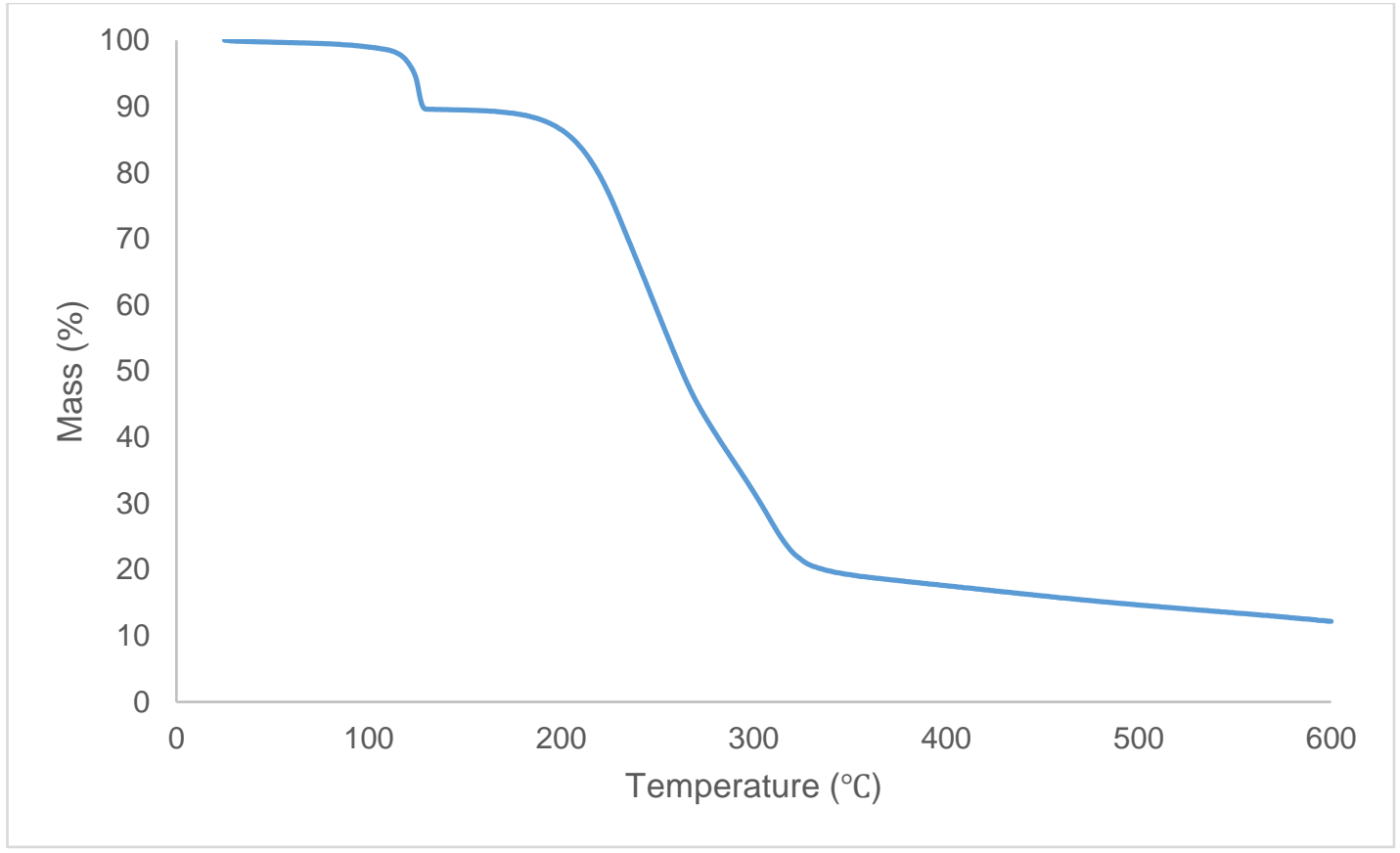

Figure S17. TGA data for solution grown TMP.INA $\cdot \mathbf{M e N O}_{2}$. A mass loss of $9.34 \%$ was observed at $103.5^{\circ} \mathrm{C}$, and crystal decomposition began at ca. $191.6^{\circ} \mathrm{C}$. 


\section{DSC data}

Crystalline samples were analyzed by DSC using Mettler Toledo DSC823 with freon cooler. All experiments were performed by heating the samples from 25 to $250{ }^{\circ} \mathrm{C}$ at a heating rate of $10{ }^{\circ} \mathrm{C} / \mathrm{min}$.

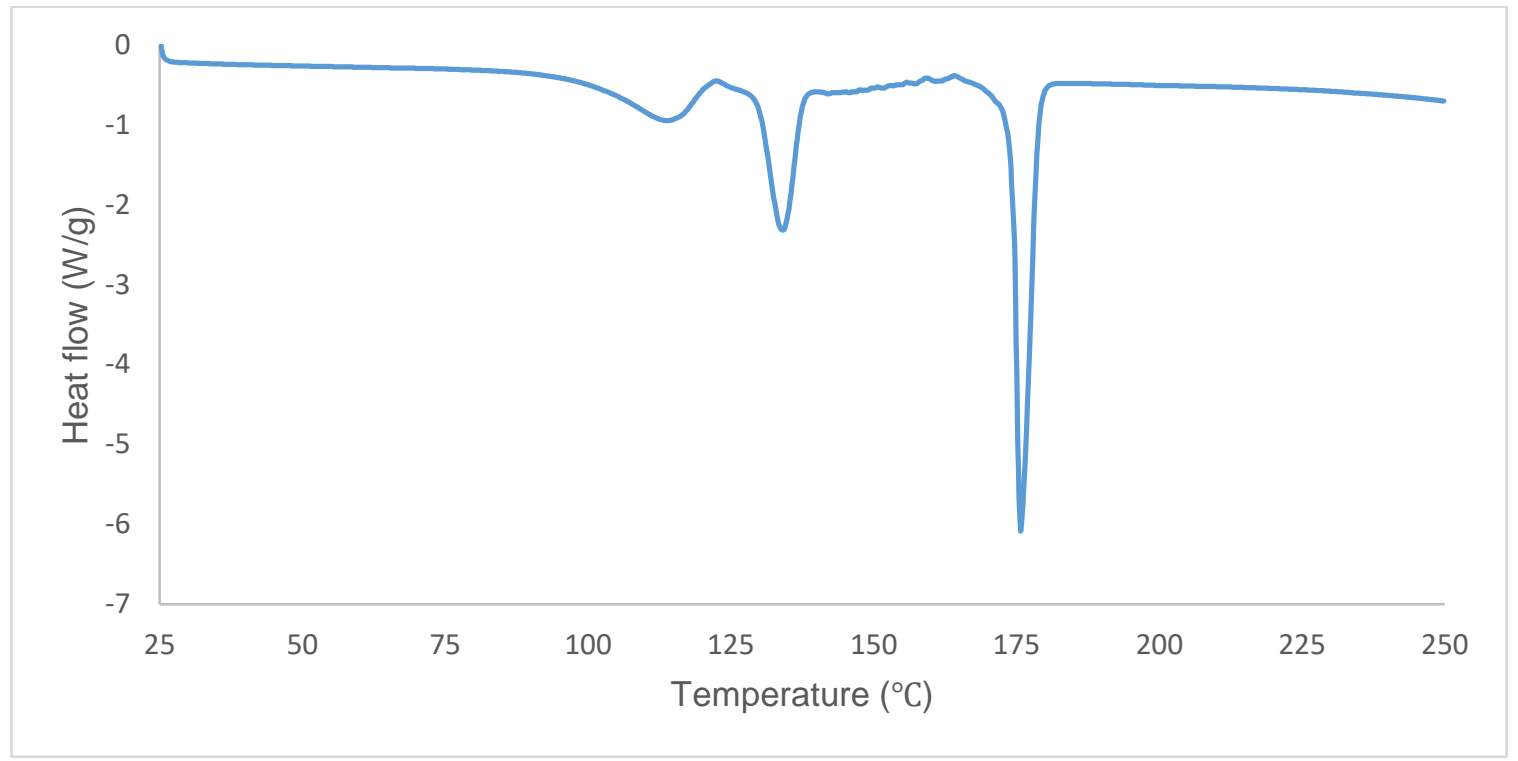

Figure S18. DSC data for solution grown TMP·NA $\cdot \mathbf{H}_{2} \mathbf{O}$ (onset: $174.27^{\circ} \mathrm{C}$, peak: $175.72{ }^{\circ} \mathrm{C}$ ).

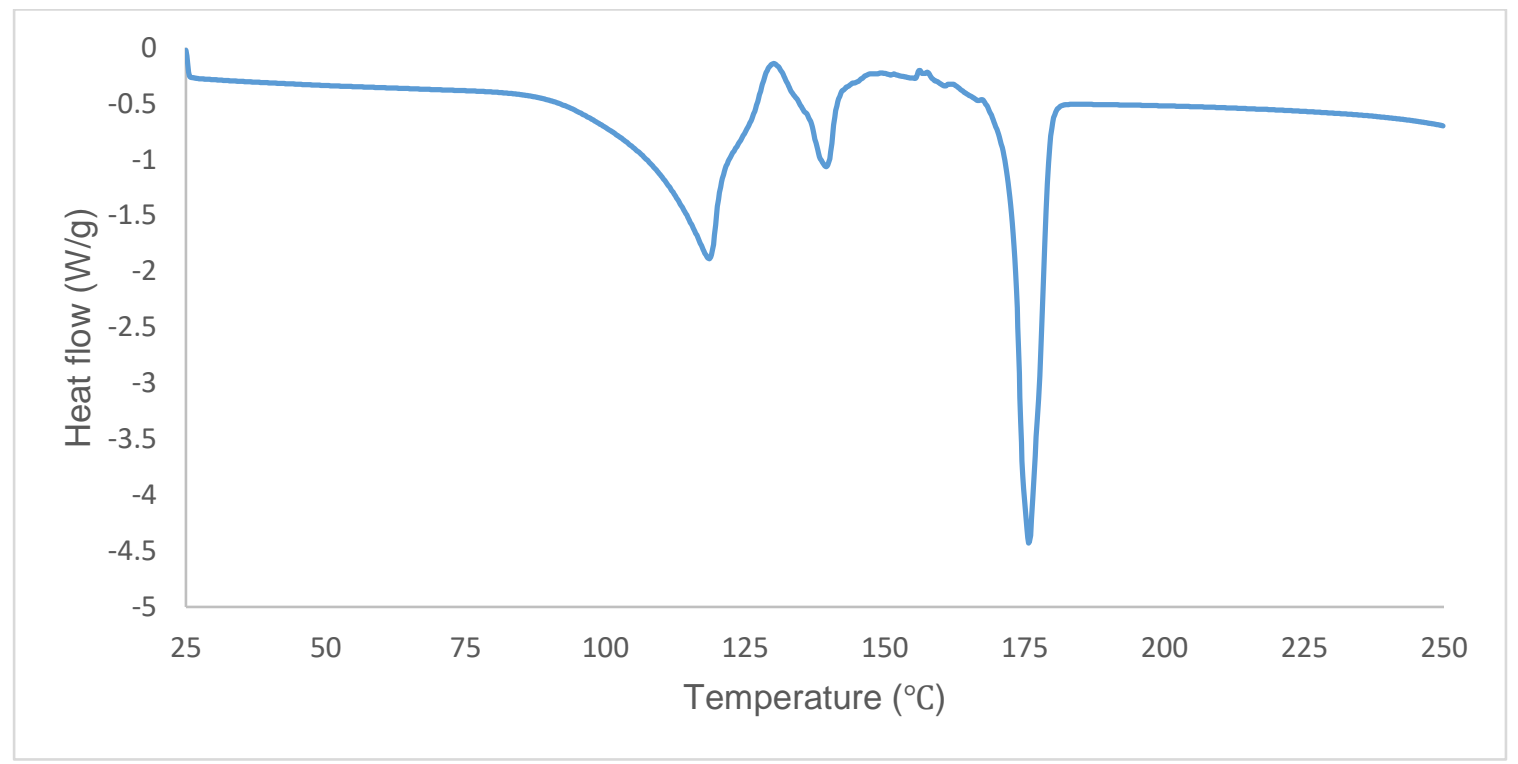

Figure S19. DSC data for solution grown TMP·NA·EtOH (onset: $172.55{ }^{\circ} \mathrm{C}$, peak: $175.70{ }^{\circ} \mathrm{C}$ ). 


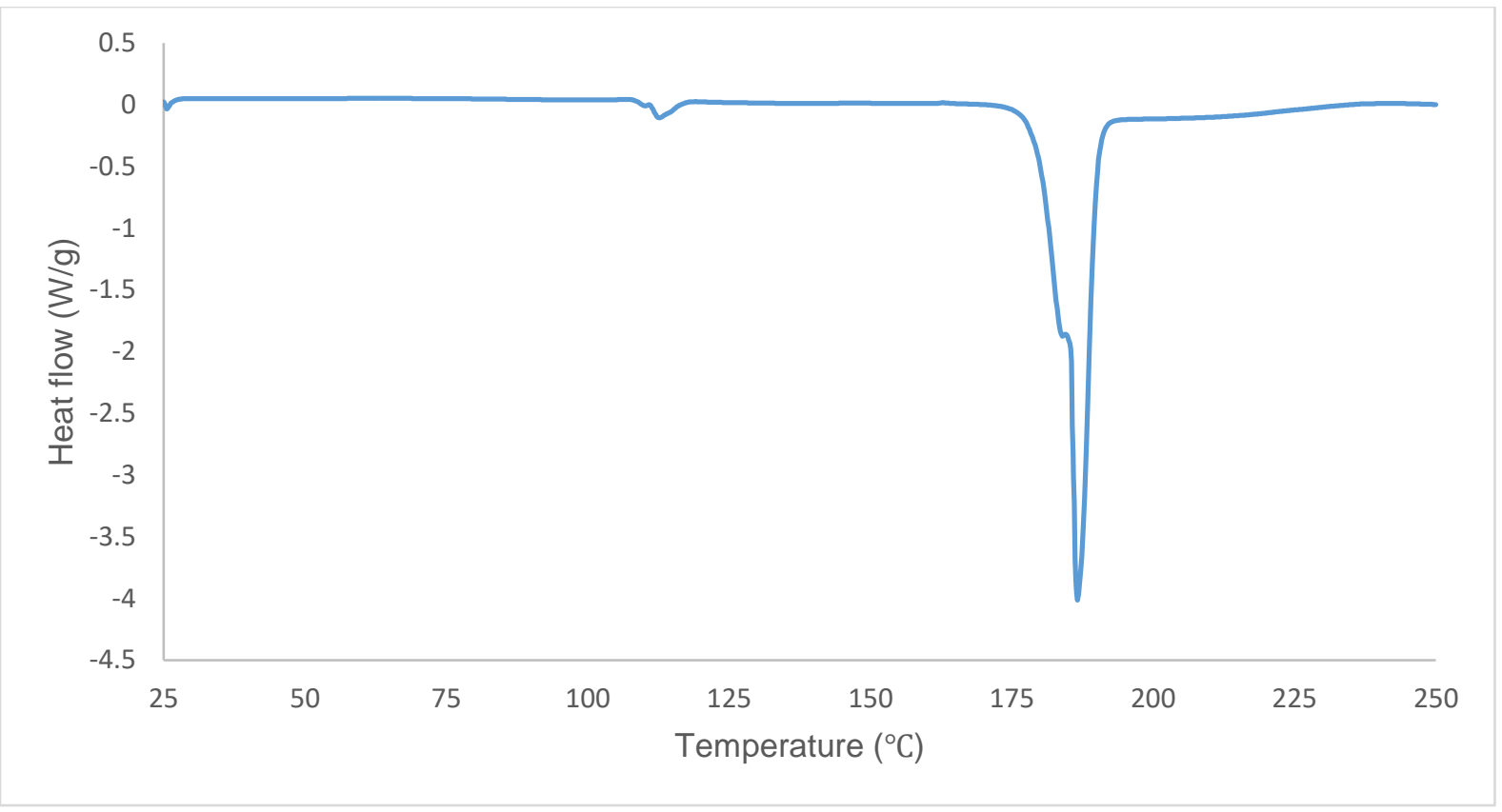

Figure S20. DSC data for solution grown TMP·INA $\cdot \mathbf{M e N O}_{2}$ (onset: $184.58{ }^{\circ} \mathrm{C}$, peak: $186.62{ }^{\circ} \mathrm{C}$ ). 


\section{Solubility, melting point, and stability experiments}

The solubility data was collected by dissolving specific amount of salt $\mathbf{T M P} \cdot \mathbf{N A} \cdot \mathbf{H}_{2} \mathbf{O}, \mathbf{T M P} \cdot \mathbf{N A} \cdot \mathbf{E t O H}$, or TMP.NA $\cdot \mathbf{M e N O}_{2}$ in specific amount of water in a vial (the specific amount of salt and water is shown in Table S3). Water was added by using a micropipette with a Kali-BT-200 tip to a vial containing each salt, and $100 \mu \mathrm{L}$ of water was transferred at a time. The vial was then oscillated in a sonicator to dissolve each salt. More water was added in the vial until a clear solution was obtained after oscillation in the sonicator.

The melting point data were collected on a DigiMelt using the visual detection capillary method.

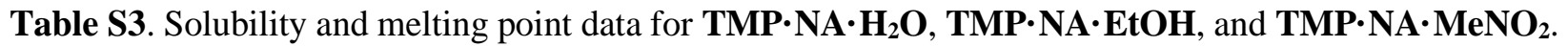

\begin{tabular}{|c|c|c|}
\hline Sample & Aqueous solubility $\left(\mathrm{mg} / \mathrm{L}, 25^{\circ} \mathrm{C}\right)$ & Melting point $\left({ }^{\circ} \mathrm{C}\right)$ \\
\hline TMP & $400^{\mathrm{a}}$ & $199-203^{\mathrm{a}}$ \\
\hline NA & $18000^{\mathrm{b}}$ & $237^{\mathrm{b}}$ \\
\hline INA & $6000^{\mathrm{c}}$ & $310-315^{\mathrm{c}}$ \\
\hline TMP·NA$\cdot \mathrm{H}_{2} \mathrm{O}$ & $4643(6.5 \mathrm{mg}$ in $1400 \mu \mathrm{L})$ & 177.5 \\
\hline TMP·NA·EtOH & $1000(2.5 \mathrm{mg}$ in $2500 \mu \mathrm{L})$ & 162.2 \\
\hline TMP.NA· $\mathrm{MeNO}_{2}$ & $4615(6.0 \mathrm{mg}$ in $1300 \mu \mathrm{L})$ & 169.6 \\
\hline
\end{tabular}

${ }^{\mathrm{a}} \mathrm{See}$ reference $4 .{ }^{\mathrm{b}} \mathrm{See}$ reference $5 .{ }^{\mathrm{c}}$ See reference 6.

The stability of the salts TMP·NA $\cdot \mathbf{H}_{2} \mathrm{O}$, TMP·NA $\cdot \mathbf{E t O H}$, and TMP·NA $\cdot \mathbf{M e N O} \mathbf{2}_{2}$ was monitored by synthesizing a fresh sample, which was characterized by PXRD. Then, each sample was placed in a vial without a cap and allowed to sit undisturbed on the bench (open to ambient air) for a period of 10 days. After 10 days, each sample was re-analyzed by PXRD (Figures S24-S26). Since TMP·NA $\cdot \mathbf{M e N O}_{2}$ showed poor correlation by PXRD, ${ }^{1} \mathrm{H}$ NMR data was collected before and after 10-day stability studies to confirm the presence or absence of the nitromethane solvent (Figures S12-S14). 


\section{Dissolution rate experiments}

Dissolution rate experiments were conducted by adding $10 \mathrm{mg}$ of $\mathbf{T M P} \cdot \mathbf{N A} \cdot \mathbf{H}_{2} \mathbf{O}$, TMP.NA $\mathbf{E t O H}$, or TMP·NA $\cdot \mathbf{M e N O}_{2}$ to a vial containing $2 \mathrm{~mL}$ phosphate buffer solution $(\mathrm{pH}=6.98)$. The sample was heated at $37{ }^{\circ} \mathrm{C}$ and stirred at $500 \mathrm{rpm}$ on a stir plate. Each sample was monitored, and the time it took for the sample to completely dissolve in the buffer solution was recorded. A total of three trials were performed for each sample. The time is denoted in seconds (s).

Table S4. Dissolution rate data for TMP, TMP·NA $\cdot \mathbf{H}_{2} \mathrm{O}$, TMP·NA $\cdot \mathbf{E t O H}$, and TMP·NA $\cdot \mathbf{M e N O}$.

\begin{tabular}{|c|c|c|c|c|}
\hline Sample & TMP & $\mathbf{T M P} \cdot \mathbf{N A} \cdot \mathbf{H}_{2} \mathrm{O}$ & TMP·NA $\cdot \mathbf{E t O H}$ & $\mathbf{T M P} \cdot \mathbf{N A} \cdot \mathrm{MeNO}_{2}$ \\
\hline trial 1 & $>1800 \mathrm{~s}(30 \mathrm{~min})$ & $134 \mathrm{~s}$ & $340 \mathrm{~s}$ & $85 \mathrm{~s}$ \\
\hline trial 2 & $>1800 \mathrm{~s}(30 \mathrm{~min})$ & $126 \mathrm{~s}$ & $358 \mathrm{~s}$ & $106 \mathrm{~s}$ \\
\hline trial 3 & $>1800 \mathrm{~s}(30 \mathrm{~min})$ & $129 \mathrm{~s}$ & $316 \mathrm{~s}$ & $143 \mathrm{~s}$ \\
\hline average & - & $130 \pm 4 \mathrm{~s}$ & $338 \pm 21 \mathrm{~s}$ & $111 \pm 24 \mathrm{~s}$ \\
\hline
\end{tabular}




\section{PXRD patterns}

The powder X-ray diffraction (PXRD) patterns for TMP•4,4'-AP, TMP•4,4'-BPE, and TMP•4,4'-BIPY were collected on a Rigaku Ultima III powder diffractometer. The diffraction pattern was obtained by scanning a $2 \theta$ range of $5-50^{\circ}$, step size $=0.02^{\circ}$, and scan time of 1.6 degrees $/ \mathrm{min}$. The X-ray source was $\mathrm{Cu} \mathrm{K} \alpha$ radiation $(\lambda=1.5418 \AA$ ) with an anode voltage of $40 \mathrm{kV}$ and a current of $44 \mathrm{~mA}$. The beam was then discriminated by Rigaku's Cross Beam parallel beam optics to create a monochromatic parallel beam. Diffraction intensities were recorded on a scintillation detector after being filtered through a $\mathrm{Ge}$ monochromator. The sample was prepared as a standard powder mount, and the diffractogram was processed through the software JADE v9.1.

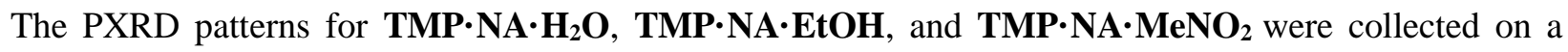
Rigaku MiniFlex II powder diffractometer. The diffraction pattern was obtained by scanning a $2 \theta$ range of $3-60^{\circ}$, step size $=0.02^{\circ}$, and scan time of 2 degrees/minute. The X-ray source was $\mathrm{Cu} \mathrm{K} \alpha$ radiation $(\lambda$ $=1.5418 \AA$ ) with an anode voltage of $30 \mathrm{kV}$ and a current of $15 \mathrm{~mA}$. Diffraction intensities were recorded on a position sensitive detector (D/teX Ultra). The sample was prepared as a standard powder mount, and the diffractogram was processed through the software MDI JADE 2020.

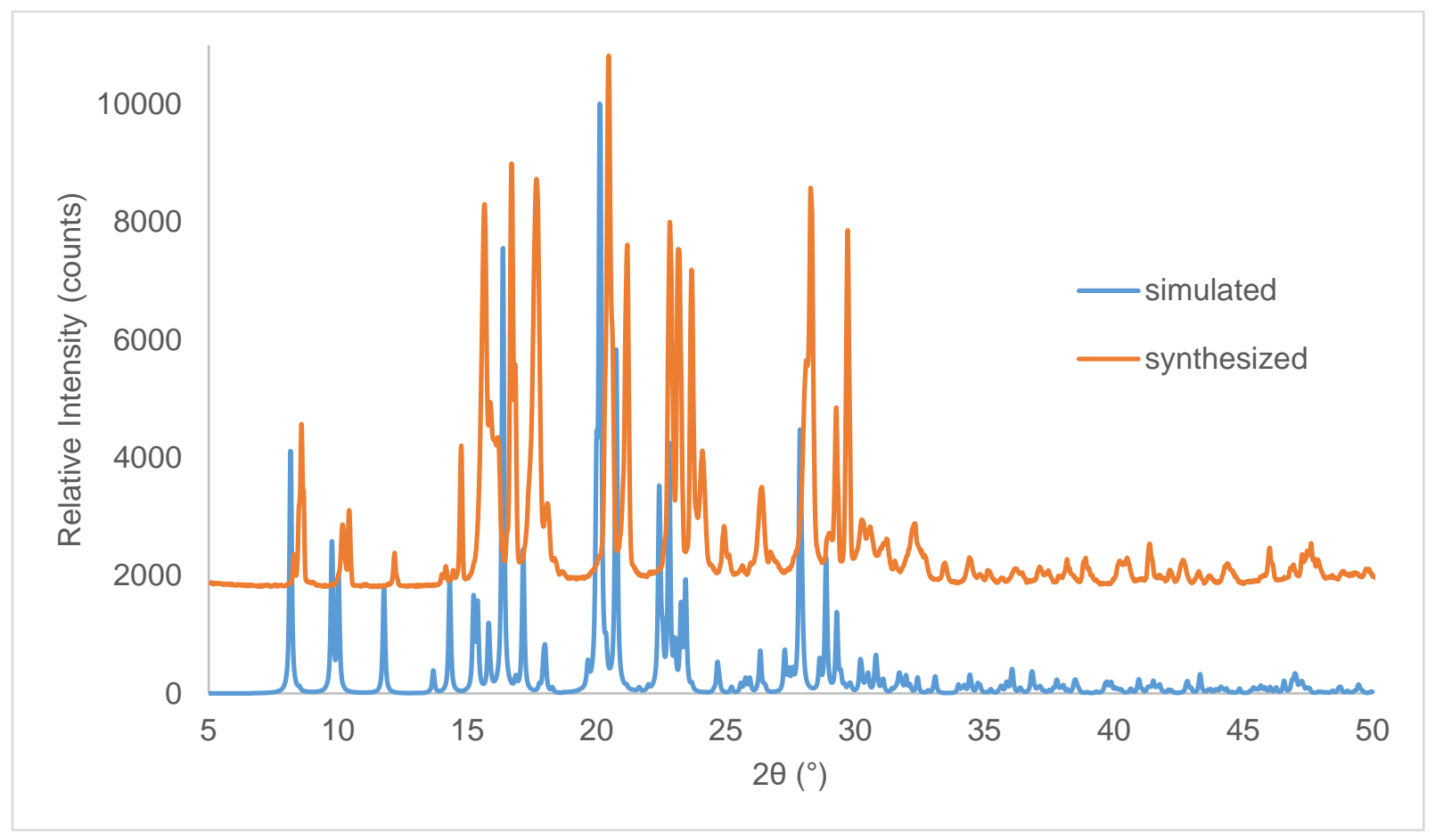

Figure S21. PXRD patterns of TMP·4,4'-AP: simulated from 290 K X-ray data and bulk cocrystal. 


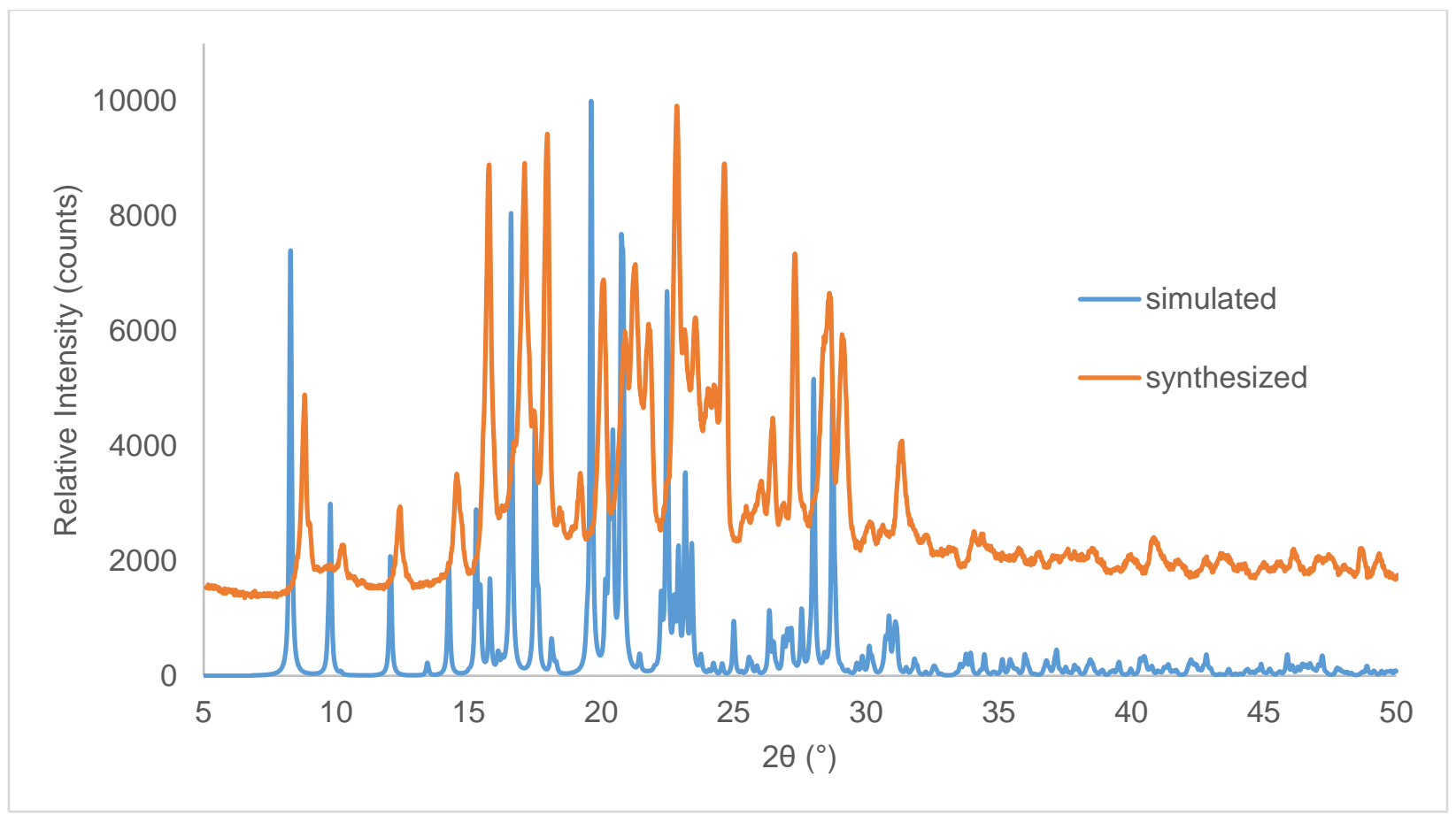

Figure S22. PXRD patterns of TMP•4,4'-BPE: simulated from 290 K X-ray data and bulk cocrystal.

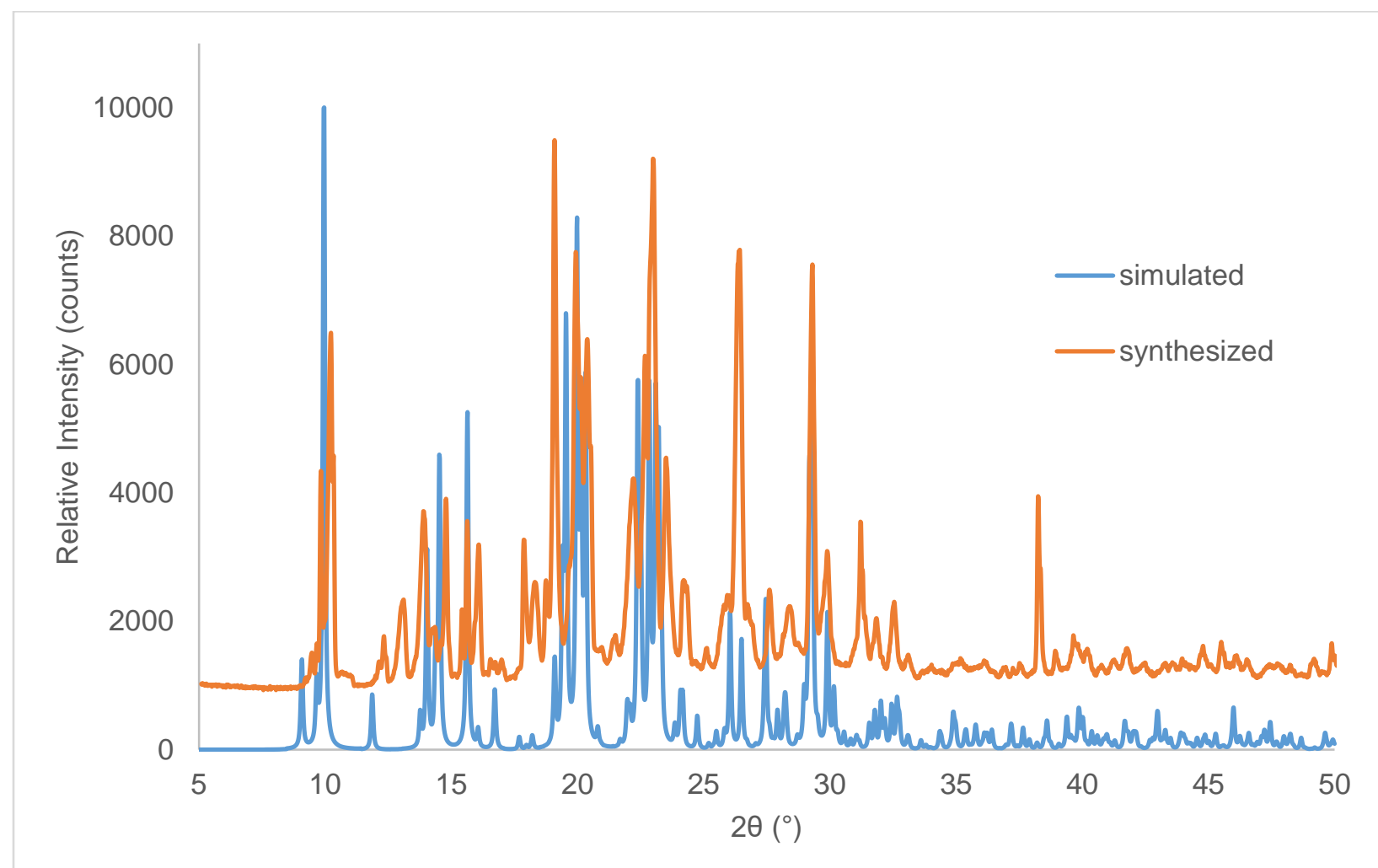

Figure S23. PXRD patterns of TMP•4,4'-BIPY: simulated from $100 \mathrm{~K} \mathrm{X-ray} \mathrm{data} \mathrm{and} \mathrm{bulk} \mathrm{cocrystal.}$ 


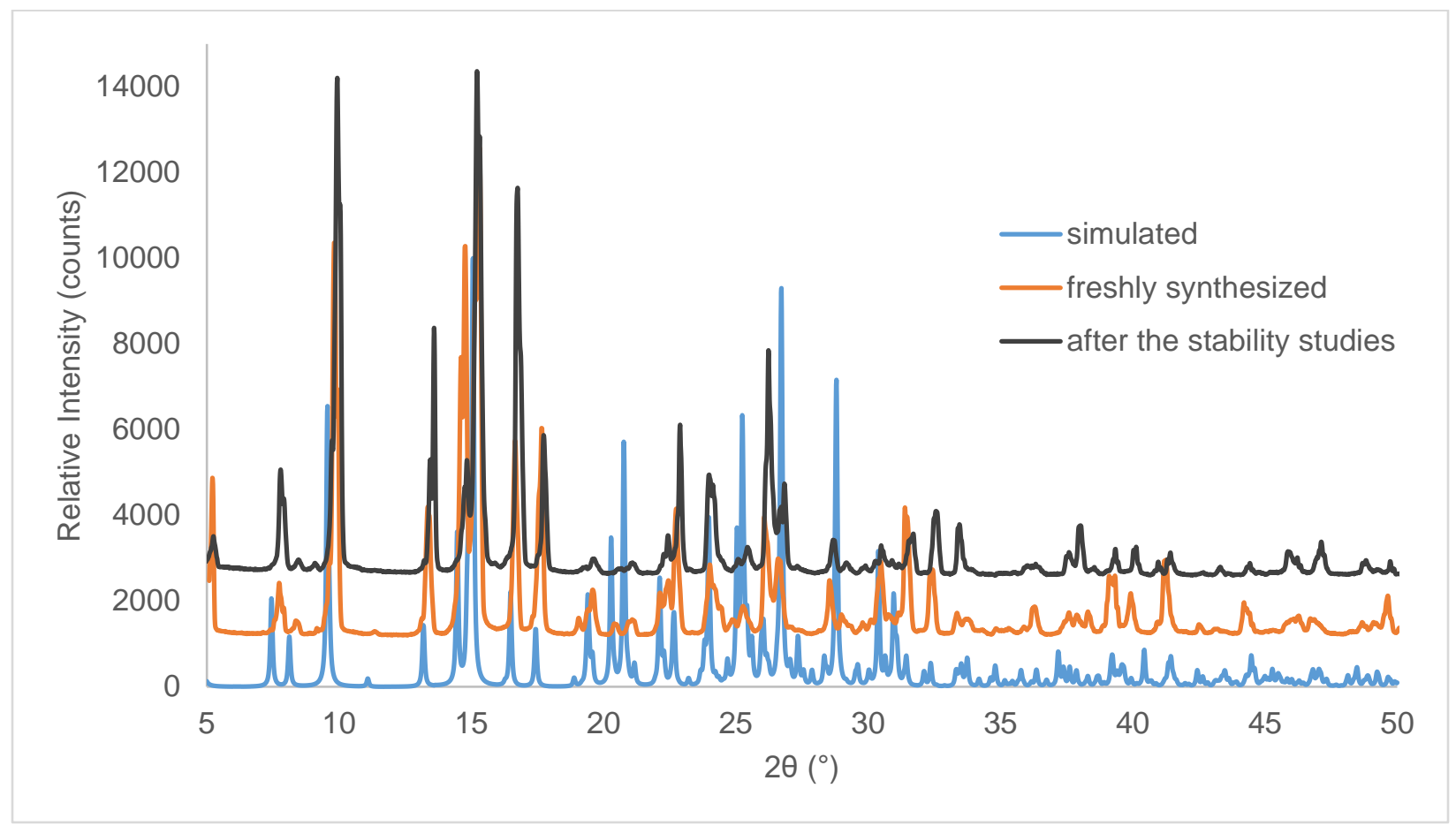

Figure S24. PXRD patterns of TMP $\mathbf{N A} \cdot \mathbf{H}_{2} \mathbf{O}$ : simulated from $100 \mathrm{~K}$ X-ray data, freshly synthesized bulk solid, and solid after 10 days of exposure to air.

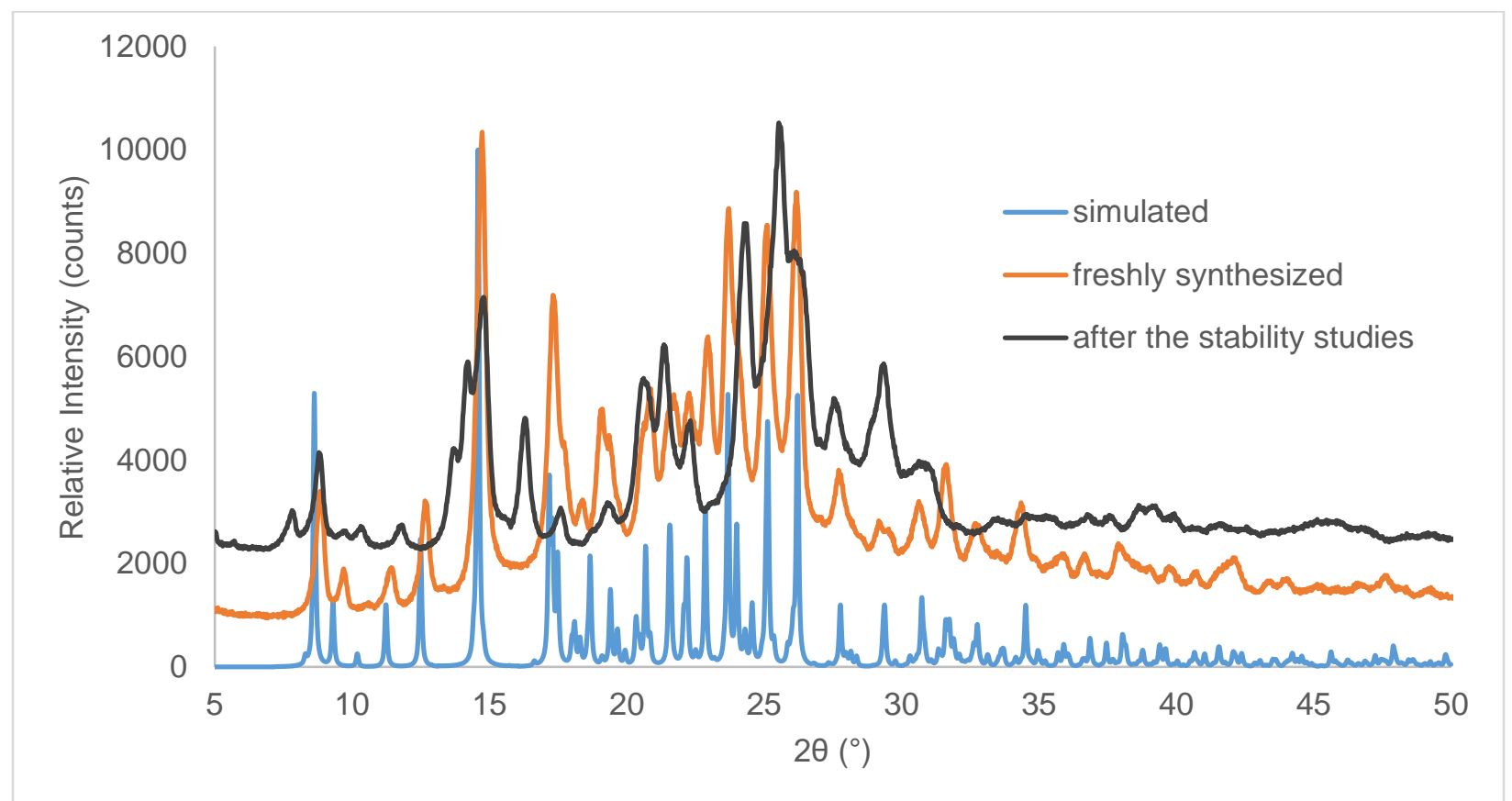

Figure S25. PXRD patterns of TMP·NA·EtOH: simulated from $100 \mathrm{~K}$ X-ray data, freshly synthesized bulk solid, and solid after 10 days of exposure to air. 


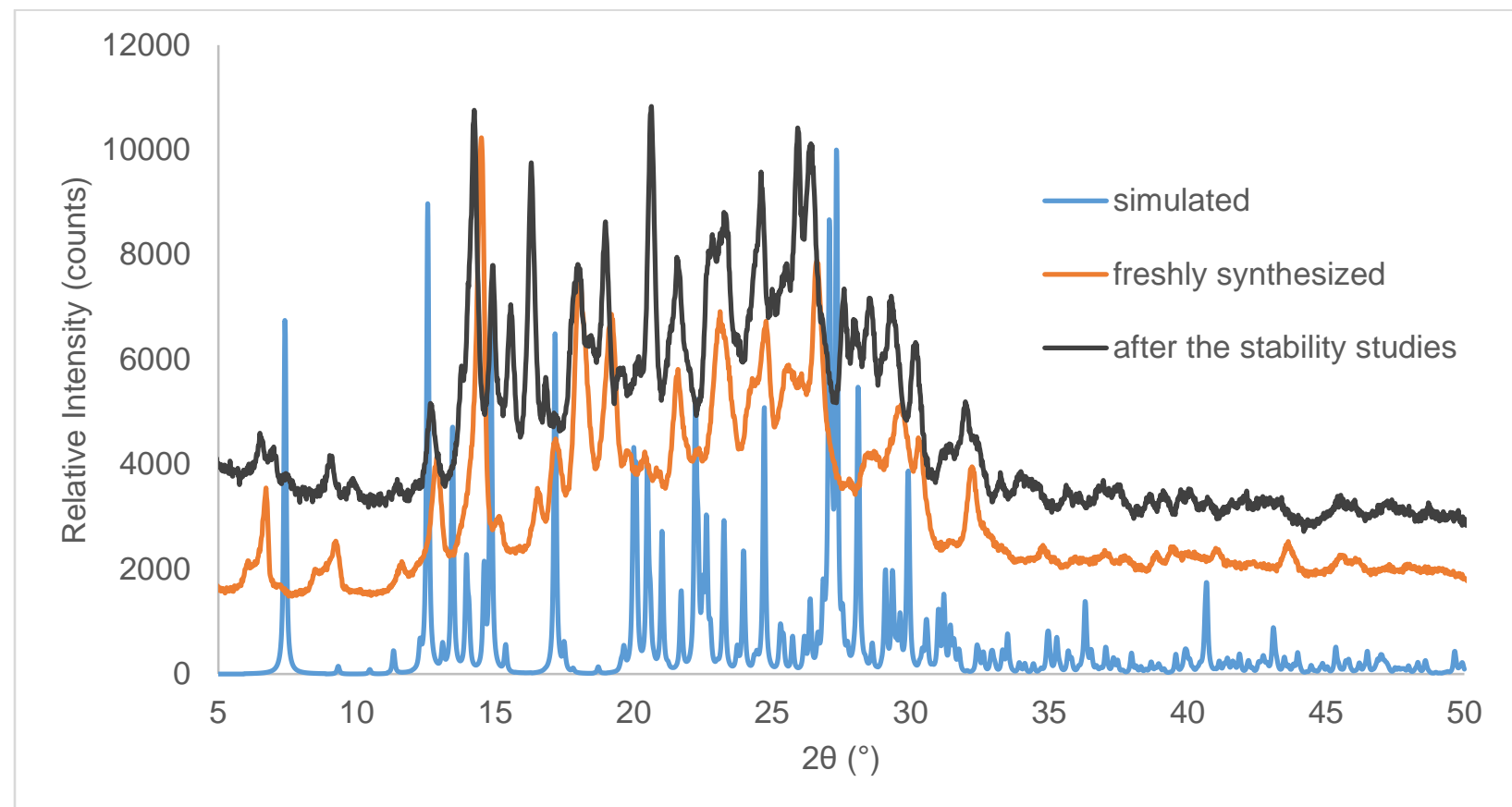

Figure S26. PXRD patterns of TMP·INA $\cdot \mathbf{M e N O}_{2}$ : simulated from $100 \mathrm{~K}$ X-ray data, freshly synthesized bulk solid, and solid after 10 days of exposure to air.

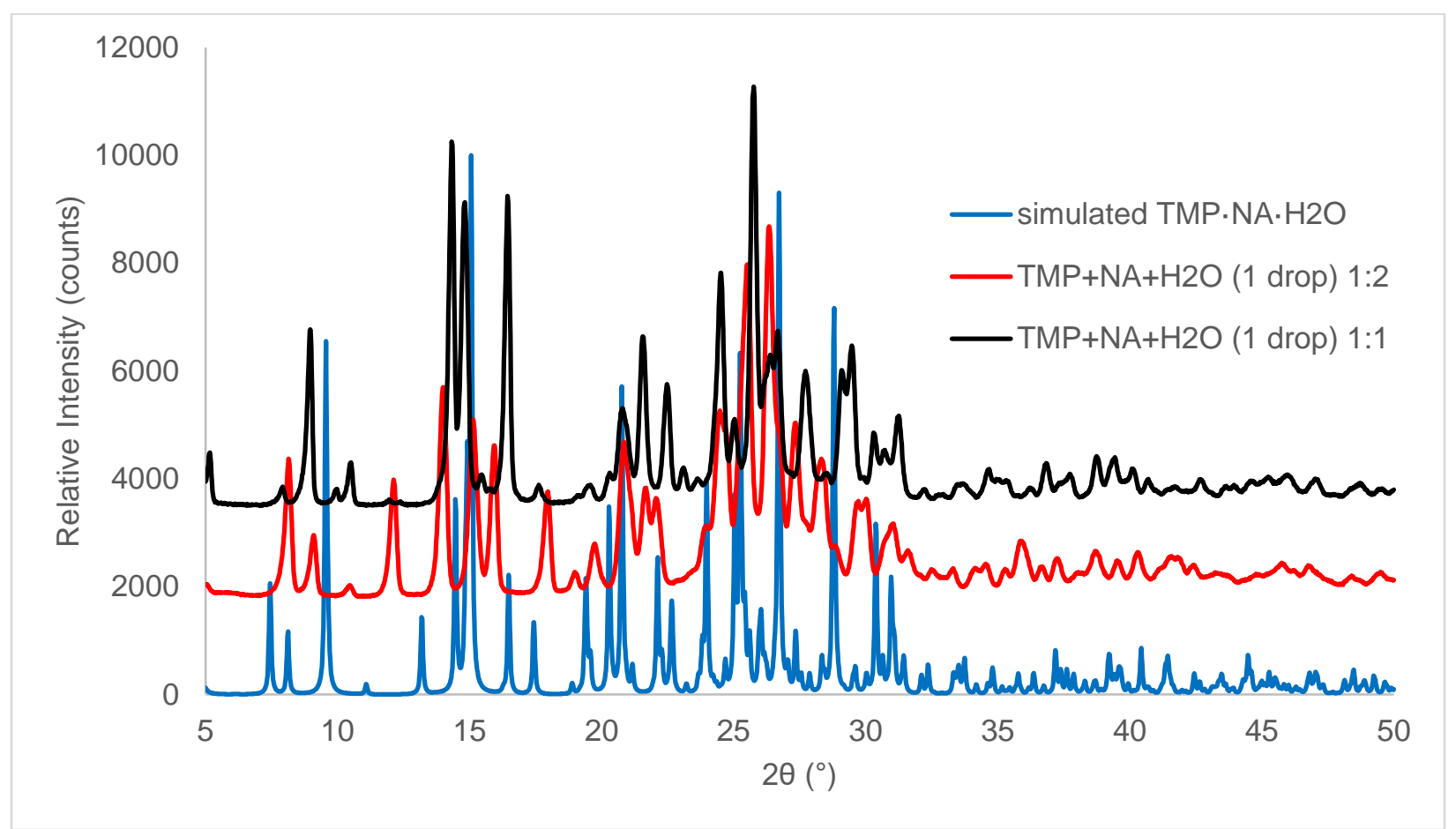

Figure S27. PXRD patterns of TMP·NA $\cdot \mathbf{H}_{2} \mathbf{O}$ : simulated from $100 \mathrm{~K}$ X-ray data and solids synthesized by mechanochemistry. Ratios used for the experiments are shown in the legend. 


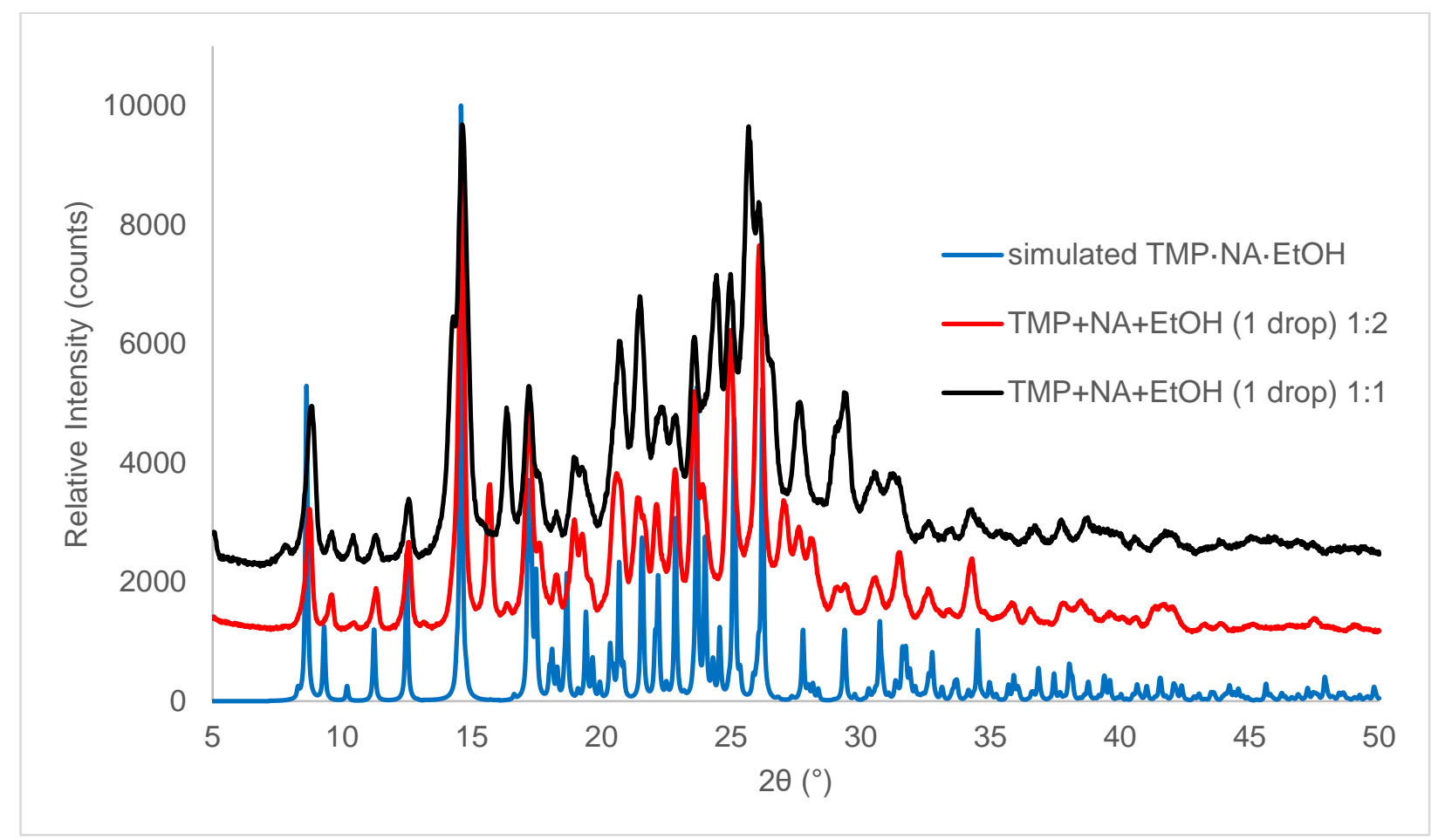

Figure S28. PXRD patterns of TMP·NA·EtOH: simulated from $200 \mathrm{~K}$ X-ray data and solids synthesized by mechanochemistry. Ratios used for the experiments are shown in the legend.

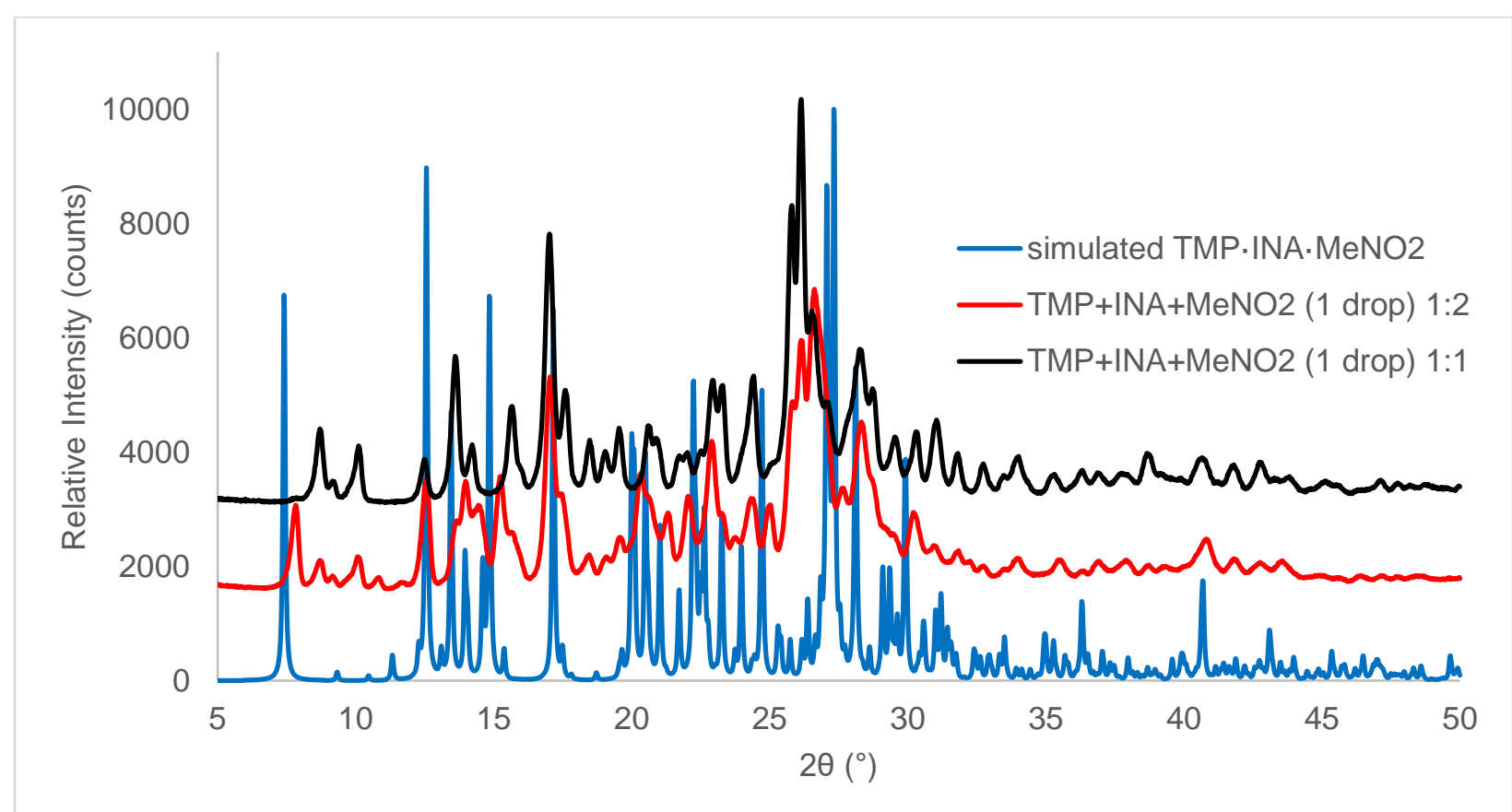

Figure S29. PXRD patterns of TMP·INA $\cdot \mathbf{M e N O}_{2}$ : simulated from $100 \mathrm{~K} \mathrm{X}$-ray data and solids synthesized by mechanochemistry. Ratios used for the experiments are shown in the legend. 


\section{References}

1.CrysAlis ${ }^{\text {Pro }}$ (2018) Oxford Diffraction Ltd.

2.SCALE3 ABSPACK (2005) Oxford Diffraction Ltd.

3. Sheldrick, G. M. Crystal structure refinement with SHELXL. Acta Crystallogr. 2015, C71, 3-8.

4. National Center for Biotechnology Information. PubChem. Trimethoprim, PubChem CID=5578; https://pubchem.ncbi.nlm.nih.gov/compound/5578 (accessed May 06, 2020).

5. National Center for Biotechnology Information. PubChem. Nicotinic acid, PubChem CID=938; https://pubchem.ncbi.nlm.nih.gov/compound/938 (accessed May 06, 2020).

6. National Center for Biotechnology Information. PubChem. Isonicotinic acid, PubChem CID=5922; https://pubchem.ncbi.nlm.nih.gov/compound/5922 (accessed May 06, 2020). 